\title{
Syntaxonomy of the Festuco-Brometea class vegetation of the Azov sea coastal zone
}

\author{
Vitaliy Kolomiychuk ${ }^{1}$ \& Denys Vynokurov²,*
}

Key words: bunchgrass steppe, classification, diagnostic species, dry grasslands, Eastern Europe, numerical analysis, TWINSPAN, vegetation.

Ključne besede: stepe z bodalico, klasifikacija, diagnostične vrste, suha travišča, vzhodna Evropa, numerična analiza, TWINSPAN, vegetacija.

Received: 20. 10. 2015

Revision received: 22. 3. 2016

Accepted: 19. 5. 2016

Co-ordinating Editor: Idoia Biurrun

\begin{abstract}
Syntaxonomy of the class Festuco-Brometea in Ukraine has barely been still explored. There are some scattered and local data, mainly within the Forest-Steppe zone, which need to be compiled and critically reviewed. Similarly, the Azov Sea coastal zone, which, despite the considerable diversity of habitats, remains unstudied phytosociologically. We have carried out large-scale comparisons of relevés from the Sea of Azov coastline with data from other regions of Ukraine, Europe, and Russia. In total, 2336 relevés were used for the analysis. For the analysis, Modified TWINSPAN classification was used. Diagnostic species were determined by means of the phi fidelity index. In total, 9 associations and 4 subassociations, belonging to four alliances, were identified and categorised as follows: Artemisio-Kochion prostratae (ruderalized steppes), Artemisio tauricaeFestucion valesiacae (saline steppe vegetation on sites affected by the sea or saline ground water), Stipo lessingianae-Salvion nutantis (forb-bunchgrass steppe vegetation) and Tanaceto millefolii-Galatellion villosae (bunchgrass steppes). The last alliance is proposed as a new one.

\section{Izvleček}

Sintaksonomija razreda Festuco-Brometea je bila dosedaj v Ukrajini slabo raziskana. Obstaja nekaj razpršenih in lokalnih podatkov, predvsem v coni gozdne stepe, ki pa jih je potrebno združiti in kritično ovrednotiti. Podobno velja za obalno območje Azovskega morja, ki kljub veliki raznolikosti habitatov ostaja fitocenološko neraziskano. Naredili smo obsežno primerjavo popisnega gradiva z obal Azovskega morja in podatki iz ostalih predelov Ukrajine, Evrope in Rusije. Skupaj smo v analizi zbrali 2336 popisov. Za analizo smo uporabili modificirano TWINSPAN klasifikacijo. Diagnostične vrste smo določili s pomočjo fi indeksa navezanosti. Ugotovili smo 9 asociacij in 4 subasociacije, ki jih uvrščamo v štiri zveze: Artemisio-Kochion prostratae (ruderalizirane stepe), Artemisio tauricaeFestucion valesiacae (slana stepska vegetacija na rastiščih z morsko vodo ali slano podtalnico), Stipo lessingianae-Salvion nutantis (stepska vegetacija z zelišči in bodalico) in Tanaceto millefolii-Galatellion villosae (stepe z bodalico). Zadnjo zvezo smo opisali na novo.
\end{abstract}




\section{Introduction}

The coastal zone of the Azov Sea lies in a unique region, both in origin and natural conditions. It is characterised by high diversity of species and ecosystems. The dominating type of vegetation is formed by a particular kind of steppe vegetation. It is characterised by lower floristic richness and less aboveground biomass compared to steppe vegetation further north. Moreover, its vegetation shows a lower average height, and less flowering aspects during the year (Dembicz et al. 2016) thought to be due to the decreasing moisture gradient.

Under the influence of human activity in the $19^{\text {th }}$ and especially the $20^{\text {th }}$ century, the landscape of the Azov sea coast was significantly transformed (Matishov et al. 2011). Residues of natural vegetation (steppe, meadow, halophytic and psammophytic communities, etc.) has only remained in some areas, particularly, at the coast, near the outputs of rocks, in areas of special protection (e.g. military sites, nature reserves, national parks) or in places inaccessible to humans (gullies, ravines, floodplains).

There are four types of steppes in the study area according to the Map of the natural vegetation of Europe (Bohn et al. 2004): 1) West and Central Pontic herb-rich grass steppes (Eastern Pryazov'ya); 2) West and central herb-grass steppes (Northern and Don Pryazov'ya); 3) West Pontic grass steppes (Northern, Kerch and Taman Pryazov'ya); 4) West and Central Pontic desert steppes (Syvash and Kerch Pryazov'ya).

Steppe vegetation of the steppe zone is considered to belong within Fescuco-Brometea class (Solomakha 2008). The majority of authors attributed this type of vegetation to the Festucetalia valesiacae order (Kostyliov et al. 1984, Tyshchenko 1996, 2000, 2006, Grechushkina et al. 2012, Korotchenko \& Peregrym 2012, Vynokurov 2014a,b). But, recent studies have shown that it should be considered as a new separate order Galatello villosaeStipetalia lessingianae nom. prov. (Vynokurov 2016). The syntaxonomy of Festuco-Brometea for the coastal zone of the Sea of Azov has previously not been developed in full. However, there are some known studies about classification of the Eastern Crimean steppes (Korzhenevskij \& Kljukin 1986, 1991, Korzhenevskij et al. 2003) from some areas of Prysyvashshia (Dubyna \& Dziuba 2007) and from Northern and Eastern Pryazov'ya (Demina 2012, Grechushkina et al. 2012, Tyshchenko 2006).

In view of the current rudimentary state of available information, the authors propose to develop and complement the classification of steppe communities of FestucoBrometea class of the coastal area of the Sea of Azov by characterising selected syntaxa.

\section{Methods}

\section{Study area}

The Sea of Azov is a small sea (approx. 39,000 $\mathrm{km}^{2}$ ) in south-eastern Europe (Figure 1) and lies southeast of Ukraine and southwesterly of Russia. The region includes the coastal areas of southern Donetsk and Zaporizhzhia, "Northern Pryazov'ya" and "Prysyvashshia" (east of the Kherson region), "Crimean Pryazov'ya" (east of the Crimea), "Don Pryazov'ya" (northwest of the Rostov region) and the region west of the Krasnodar ("Eastern Pryazov'ya"). The basin of the Sea of Azov is mostly shallow. Its topography is broken up by subsea elevations emerging in submeridional direction and by a broad belt of about $20-30 \mathrm{~km}$ in width of very shallow water $(6-7$ meters).

The area of the sea without Syvash Bay and the estuaries amounts to $37802 \mathrm{~km}^{2}$ (Tyshchenko 2006). The coast of
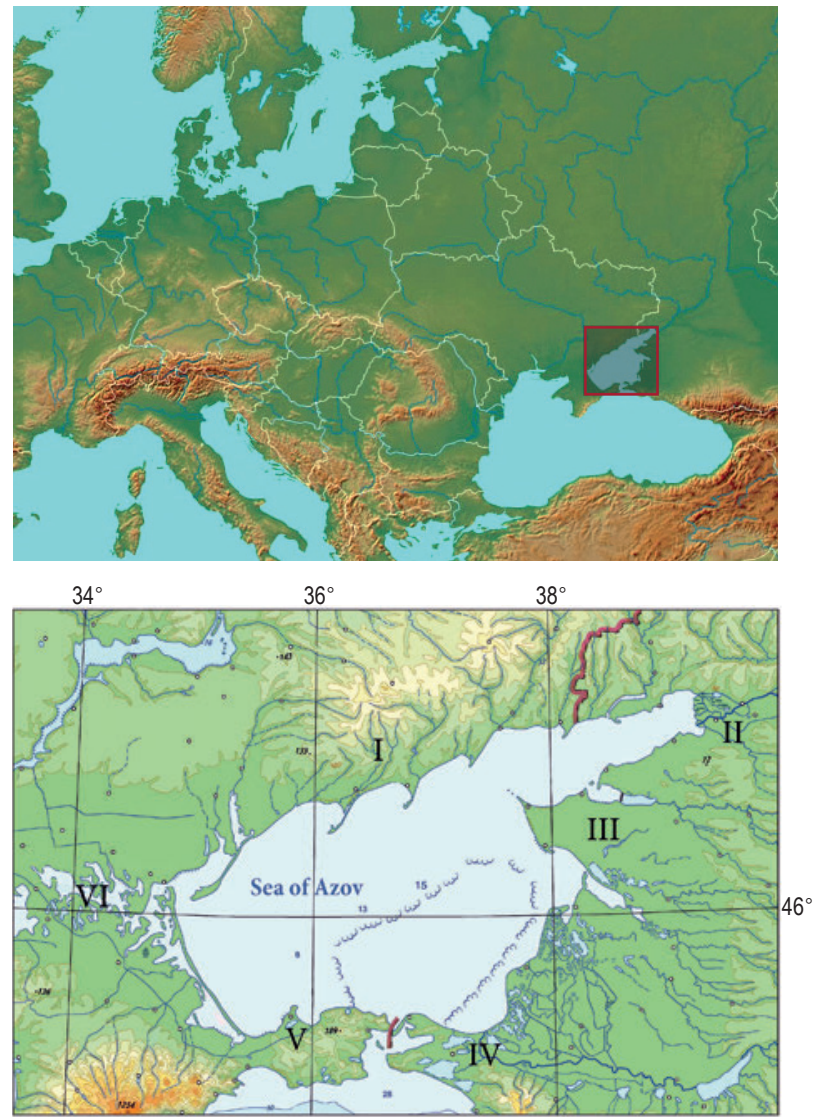

Figure 1: Location of the study area within Europe. I - Northern Pryazov'ya, II - Don Pryazov'ya, III - Eastern Pryazov'ya, IV - Kerch Pryazov'ya, V - Taman Pryazov'ya, VI - Syvash.

Slika 1: Lokacija preučevanega območja v Evropi: I - severni del Pryazov'ya, II - Don Pryazov'ya, III - vzhodni del Pryazov'ya, IV - Kerch Pryazov'ya, V-Taman Pryazov'ya, VI - Syvash. 
the Sea of Azov are mainly composed of friable abrasive rocks of the Neogene and the Quaternary (Kaplin et al. 1991) intensively influenced by erosion of the sea. Steppe alluvial and loess plains reach close to the sea almost along the entire coastline. They are formed on structures of ancient (Russian Precambrian) and younger (Scythian) platforms. Bedrock coast mainly takes the form of a cliff. It is formed by rocks of the Upper Neogene and Quaternary (Shnyukov et al. 1974).

According to the geobotanical zoning of Ukraine the study area belongs to the Prychornomor'ya (Pontic) steppe province of the Eurasian steppe region (Didukh \& Shelyag-Sosonko 2003). The sea coast lies within one of the three stripes of the Chornomor'ya-Azov steppe subprovince in the Pontic province (Barbarych 1977), namely: forb-bunchgrass (Pryazov'ya district and part of Kerch-Taman geobotanical district); bunchgrass (Dnieper-Azov, Azov-Egorlyk and part of Kerch-Taman geobotanical districts); and strip of sagebrush steppes (Prysyvashshia geobotanical district), which covers the territory adjacent to Syvash Bay in the Sea of Azov.

\section{Data collection}

The classification of steppe vegetation of the class Festuco-Brometea of the coastline of the Sea of Azov has been developed on the basis of own geobotanical research carried out from 2002 to 2014 in the Ukraine (Donetsk, Zaporizhzhia, and Kherson regions, the Autonomous Republic of Crimea) and in Russia (Rostov region and Krasnodar territory). 478 relevés of 16 to $100 \mathrm{~m}^{2}$ plot size were sampled in the study area according to the BraunBlanquet approach (Braun-Blanquet 1964, Westhoff \& van der Maarel 1973). Most importantly, the vegetation samples had to meet the criterion of homogeneity. In addition to that, published data from other syntaxonomy studies on coastal steppe vegetation of the Azov Sea was implemented into the data set (62 relevés) (Tyshchenko 1996, 1998, 2000, Dubyna \& Dziuba 2007, Grechushkina et al. 2012). Plot sizes ranged from 16 to $100 \mathrm{~m}^{2}$.

Furthermore, 1758 relevés of Festuco-Brometea class from other regions were also used. 466 of them, sampled by D. Vynokurov (2009-2013) in neighbouring areas of the steppe zone of Ukraine, were obtained from the Ukrainian Grassland Database (EU-UA-001) (Chytrý et al. 2016). The rest of relevés (1292) from Ukraine, Eastern Europe and Russia were compiled from different literature sources (bibliographic references listed in Vynokurov 2014a). The final data set of 2336 relevés in total was arranged using TURBOVEG 2.0 (Hennekens \& Schaminée 2001).
Further on, only relevés clearly suborded to the class Festuco-Brometea were included in the data set: This means that relevés with more than $50 \%$ of their species diagnostic to other related classes (e.g. to the Artemisietea vulgaris Lohmeyer et al. ex Von Rochow 1951 or Festucetea vaginatae Soó ex Vicherek 1972) were removed from the dataset. Because of this, all communities described by Grechushkina et al. (2012), for example, were rejected as they are transitional between steppe, psammophytic and ruderal vegetation.

For the analysis, species which were only determined to genus level and cryptogams were removed from the dataset. Also, some taxonomically ambiguous species were combined into aggregates (Table 1). Nevertheless, species names are given in narrow understanding without combining into aggregates for the description of the considered syntaxa.

\section{Data analysis}

Vegetational classification was conducted by means of Modified TWINSPAN (Roleček et al. 2009), implemented in the software package JUICE 7.0 (Tichý 2002). We used the default settings of JUICE (with three pseudospecies cut levels: $0 \%, 5 \%$ and $15 \%$; minimum group size: 5; Whittaker's beta) and tried cluster numbers of up to 15. The analysis was conducted in two steps. First, the entire data set was processed with Modified TWINSPAN to identify the high level syntaxa at alliance level. Secondly, each cluster with relevés from the study area was analysed separately using Modified TWINSPAN with the same parameters as above. Next, associations and subassociations were identified. The type relevés of the associations were used to identify associations within clusters. New associations were established when no types were matched with a cluster.

To identify diagnostic species, the phi fidelity index was used (Chytrý et al. 2002). It was calculated using presence-absence data with standardization of all groups of relevés to equal size. Non-essential values of fidelity (less than 0.001) were removed on the basis of Fischer's exact test. Fidelity indices were calculated first for the level of association and subassociation. Diagnostic species for the alliance level were calculated after merging associations in alliances. We considered species as diagnostic when phi > $25 \%$ and as highly diagnostic when phi $>50 \%$ (written in bold letters in the current article); constant species, with frequencies $>25 \%$; highly constant species with frequencies $>50 \%$ (also bold). As dominant species we considered those with a mean cover of more than $25 \%$, with a $10 \%$ threshold of frequency. 
Syntaxa names were specified according to the International Code of Phytosociological Nomenclature (Weber et al. 2000). Species names are given by "Vascular plants of Ukraine. A nomenclatural checklist" (Mosyakin \& Fedoronchuk 1999).

\section{Results}

The most fitting cluster pattern divided the entire data set into 8 clusters, which could be interpreted as alliances (except cluster D which includes 3 alliances) as they had clear ecological and floristical differences $(\mathrm{A}-\mathrm{H}$ in the dendrogram, Figure 2). Clusters A (ruderal steppe communities of Artemisio-Kochion prostratae), B (saline steppes of alliance Artemisio tauricae-Festucion valesiacae), $\mathrm{C}$ (bunchgrass steppes) and $\mathrm{H}$ (forb-bunchgrass steppes of Stipo lessingianae-Salvion nutantis) consisted of relevés from the coast of the Sea of Azov, as well as other relevés from the south of the steppe zone. Cluster $\mathrm{C}$ did not correspond to any syntaxonomical unit at alliance level. Therefore, we propose a new alliance Tanaceto millefoliiGalatellion villosae for the communities of this cluster. Details of the remaining clusters (D, E, F, G), which do not contain any relevés from the study area, are outlined in our earlier publications (Vynokurov 2014a, 2014b).

The second step of the analysis yielded only one association for the relevés from the study area within cluster A. It was matched to the Goniolimono taurici-Poetum angustifoliae, described by Tyshchenko (1996) for the area of "Obitochna Kosa" Reserve in Northern Pryazov'ya. In cluster $\mathrm{B}$ we distinguished between three associations: one

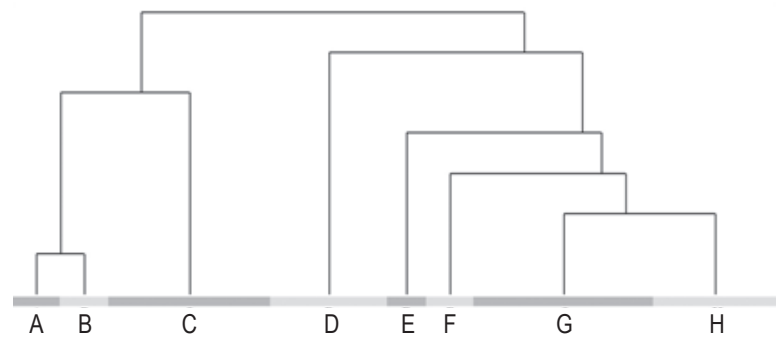

Figure 2: Dendrogram for the steppe vegetation after the first step of the analysis (Modified TWINSPAN, Pseudospecies cut level: 3; cut level values: 0, 5, 15; Minimum group size: 5; Whittaker's beta).

A-H - alliances: A - Artemisio-Kochion prostratae, B - Artemisio tauricae-Festucion valesiacae, C - Tanaceto millefolii-Galatellion villosae, D - Festucion valesiacae, Stipion lessingianae, Cirsio-Brachypodion pinnati, E - Potentillo arenariae-Linion czerniaevii, F - Poo bulbosae-Stipion graniticolae, G - Festucion valesiacae (incl. Fragario viridis-Trifolion montani), $\mathrm{H}$ - Stipo lessingianae-Salvion nutantis.

Slika 2: Dendrogram stepske vegetacije po prvem koraku analize (modificiran TWINSPAN, odrezani nivo psevdo vrst: 3; vrednosti odrezanega nivoja: $0,5,15$; minimalna velikost skupine: 5 ; Whittaker beta). A-H - zveze glej zgoraj. was matched to Ferulo orientalis-Agropyretum pectinati, described by Tyshchenko (2000) for Stepok Island (Fedotova Spit). The other two associations have to be described as new ones: Agropyro pectinati-Artemisietum tauricae and Cerastio syvashici-Poetum bulbosae. The third cluster (C), comprising four associations, is the largest one. Two of them did not match any type relevé and should be considered as new: Stipo brauneri-Bromopsidetum cappadocicae and Ephedro distachyae-Stipetum capillatae. Within these new associations, we further differentiated between four subassociations. The other two units of the cluster C match the associations Tanaceto millefolii-Salvietum nemorosae described by Krasova \& Smetana (1999) from the northern part of the bunchgrass steppe zone in the Dnipropetrovsk region and Stipo ucrainicae-Agropyretum pectinati, described by Tyshchenko (1996) for the area of "Obitochna Kosa" Reserve. Cluster H, yielded only one association for the relevés from the study area and was assigned to our newly defined association Stipo lessingianaeSalvietum nutantis. In total, nine associations and four subassociations were identified in the second step of analysis. The corresponding synoptic table is shown in Table 2 and their distribution displayed in Figures 3 and 4. Individual relevés of the new associations are given in Tables 3 and 4 .

\section{Discussion}

All of steppe vegetation of the coastline of the Sea of Azov can be categorised to the Festuco-Brometea class. Yet, it strongly distinguishes itself from other European steppe vegetation by the absence, or insignificant participation, of xero-mesic species from Central-European and EuroSiberian forest steppes (e.g. Anthyllis vulneraria, Astragalus monspessulanus, Betonica officinalis, Carex caryophyllea, C. flacca, C. humilis, Centaurea jacea, Festuca rubra, Fragaria viridis, Galium mollugo, Knautia arvensis, Linum catharticum, Luzula campestris, Pimpinella saxifraga, Poterium sanguisorba, Primula veris, Salvia pratensis, Salvia verticillata, Thymus praecox, Trifolium montanum, Viola hirta, etc.) (Dúbravková-Michálková et al. 2008, Dúbravková \& Koštál 2012, Vassilev et al. 2012, Foggi et al. 2014, Sopotlieva \& Apostolova 2014). Additionally, coastal steppe vegetation of the Sea of Azov is characterised by large number of Pontic species not especially common to Central Europe, namely: Artemisia lerchiana, Artemisia taurica, Astragalus ucrainicus, Bellevalia sarmatica, Euphorbia stepposa, Galatella villosa, Jurinea arachnoidea, Salvia nutans, Stipa lessingiana, S. ucrainica, Tanacetum millefolium, T. achilleifolium, etc. We propose to place this type of vegetation in the new order Galatello villosae-Stipetalia lessingianae Vynokurov ord. nov. prov., which includes 

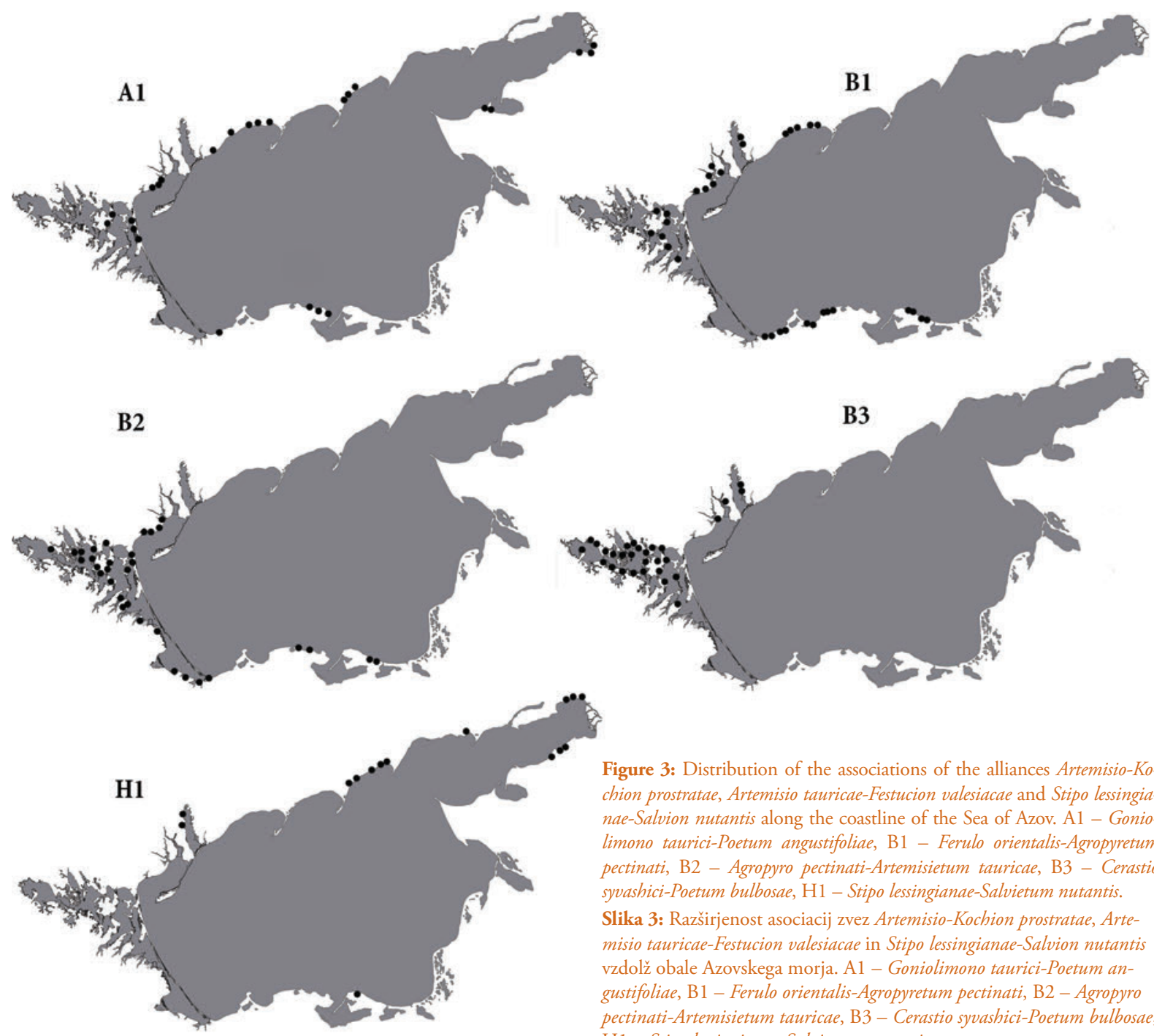

Pontic-Caspian true steppe vegetation (Vynokurov 2016). Clusters D-G in the dendrogram (Figure 2) should be placed in the Festucetalia valesiacea order.

The alliance Artemisio-Kochion prostratae includes steppe communities, which has become ruderal due to overgrazing. Dubyna \& Dziuba (2007) suggested two associations for this alliance for the territory of the AzovSyvash National Park: Artemisio austriacae-Poetum bulbosae Pop 1970 and Agropyro pectinati-Kochietum prostratae Zólyomi 1958. However, the analysis showed that these names were used not in the proper understanding but as pseudonyms for Goniolimono taurici-Poetum angustifoliae, described by Tyshchenko (1996) for the study area.

Association A1. Goniolimono taurici-Poetum angustifoliae Diagnostic species: Elytrigia repens, Euphorbia virgata, Thalictrum minus.

Figure 3: Distribution of the associations of the alliances Artemisio-Kochion prostratae, Artemisio tauricae-Festucion valesiacae and Stipo lessingianae-Salvion nutantis along the coastline of the Sea of Azov. A1 - Goniolimono taurici-Poetum angustifoliae, B1 - Ferulo orientalis-Agropyretum pectinati, B2 - Agropyro pectinati-Artemisietum tauricae, B3 - Cerastio syvashici-Poetum bulbosae, H1 - Stipo lessingianae-Salvietum nutantis.

Slika 3: Razširjenost asociacij zvez Artemisio-Kochion prostratae, Artemisio tauricae-Festucion valesiacae in Stipo lessingianae-Salvion nutantis vzdolž obale Azovskega morja. A1 - Goniolimono taurici-Poetum angustifoliae, B1 - Ferulo orientalis-Agropyretum pectinati, B2 - Agropyro pectinati-Artemisietum tauricae, B3 - Cerastio syvashici-Poetum bulbosae, H1 - Stipo lessingianae-Salvietum nutantis.

Constant species: Achillea millefolium, Agropyron pectinatum, Centaurea diffusa, Dactylis glomerata, Falcaria vulgaris, Festuca valesiaca, Medicago falcata, Phlomis pungens, Poa angustifolia, Poa bulbosa, Salvia nemorosa, Senecio vernalis, Silene otites aggr., Tragopogon dubius.

Dominant species: Elytrigia repens, Festuca valesiaca.

Communities of the association are distributed mainly on the slopes of the sea cliffs and surrounding uplands in the Northern (from Rostov-on-Don in the east and Prysyvashshia in the west), Eastern and Crimean Pryazov'ya. In particular, they are common for slopes to Kryva, Samsonova, Bilosarayska, Obitochna, Ochakivska spits, and sometimes along the right banks of Molochny and Utlyutsky estuaries (Figure 3). These communities are characterised by the dominance of rhizomatous and loose bunchgrasses (Elytrigia repens, Poa angustifolia, Agropyron pectinatum) and the co-dominance of xerophilous forbs 


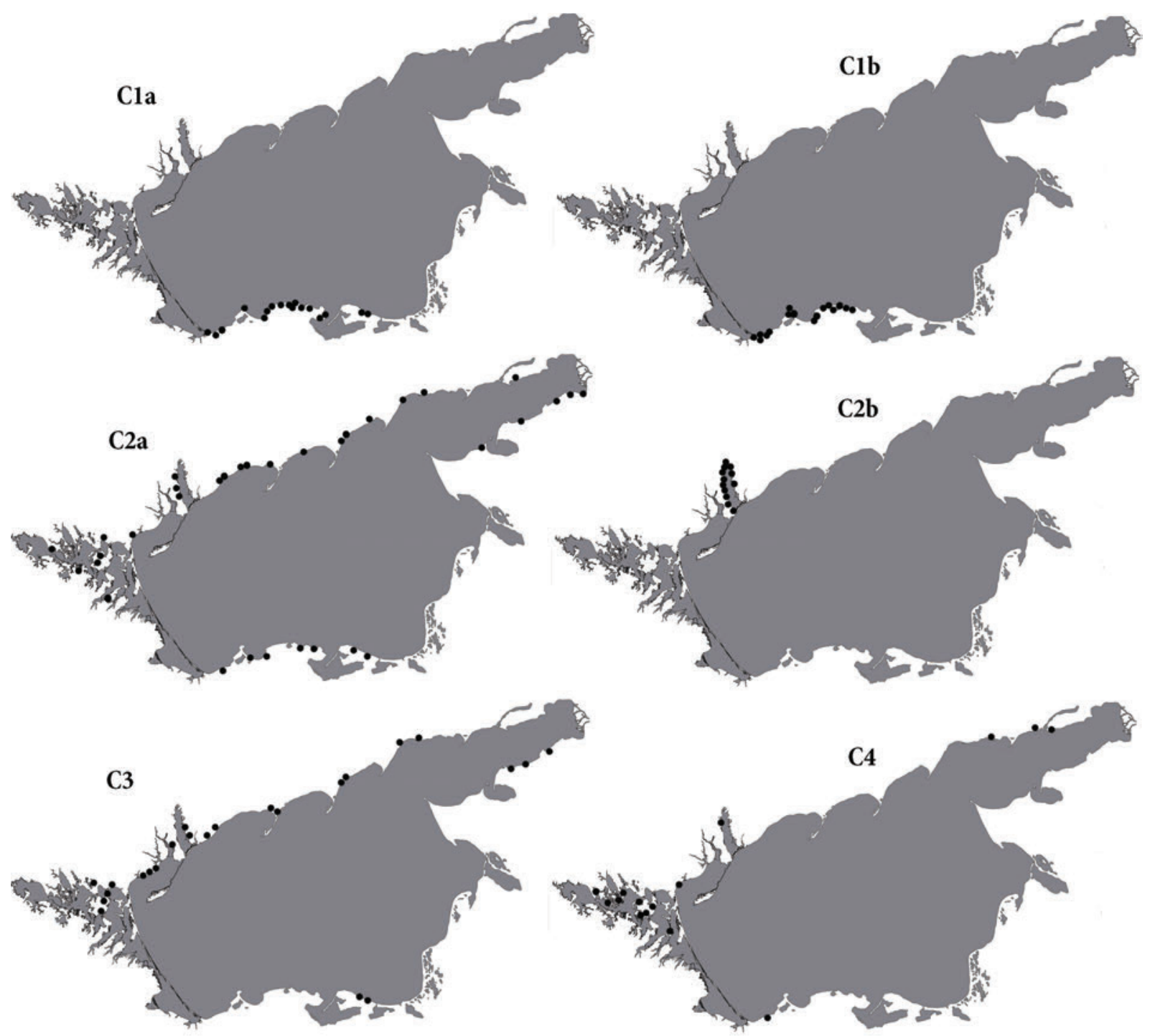

Figure 4: Distribution of the associations and subassociations of the alliance Tanaceto millefolii-Galatellion villosae along the coastline of the Sea of Azov. C1a - Stipo brauneri-Bromopsidetum cappadocicae typicum, C1b - Stipo brauneri-Bromopsidetum cappadocicae jurineetosum stoechadifoliae, C2a - Ephedro distachyae-Stipetum capillatae typicum, C2b - Ephedro distachyae-Stipetum capillatae helichrysetosum arenarii, C3 - Tanaceto millefoliiSalvietum nemorosae, C4 - Stipo ucrainicae-Agropyretum pectinati.

Slika 4: Razširjenost asociacij in subasociacij zveze Tanaceto millefolii-Galatellion villosae vzdolž obale Azovskega morja. C1a - Stipo brauneriBromopsidetum cappadocicae typicum, $\mathrm{C} 1 \mathrm{~b}$ - Stipo brauneri-Bromopsidetum cappadocicae jurineetosum stoechadifoliae, C2a - Ephedro distachyaeStipetum capillatae typicum, C2b - Ephedro distachyae-Stipetum capillatae helichrysetosum arenarii, C3 - Tanaceto millefolii-Salvietum nemorosae, C4 - Stipo ucrainicae-Agropyretum pectinati.

(Marrubium praecox, Kochia prostrata, Salvia nemorosa, etc.). Firm bunchgrasses of the genera Stipa and Festuca are few because of erosion processes on the slopes. Total vegetation cover of these communities is about $80 \%$. The accumulative species richness of vascular plants in the communities of the association sums up to 284 .

The alliance Artemisio tauricae-Festucion valesiacae comprises saline steppe vegetation. It was described on mud volcanoes of the Kerch Peninsula by Korzhenevskij \& Kljukin (1991) within the order Festucetalia valesiacae. Ac- cording to the common approach this type of vegetation is classified as desert steppes (Bilyk 1973). In Ukraine such communities are distributed in the far south of the steppe zone, Prysyvashshia, in the lowlands along the Black Sea and along the Sea of Azov, between the Dnieper and Molochna rivers, and in the Crimean Prysyvashshia. In Russia, the communities of the alliance appear in the valley of the Manych river and along the coastline of the Caspian Sea. Korzhenevskij \& Kljukin (1991) have suggested one association within this alliance, named Ferulo orientalis- 
Artemisietum tauricae, which combines specific coenoses on mud volcanoes much less common to the study area. They are quite different floristically from saline-steppe communities prevailing in the Sea of Azov coastline.

Association B1. Ferulo orientalis-Agropyretum pectinati Diagnostic species: Artemisia santonicum, Bupleurum marschallianum, Elytrigia elongata, Limonium gmelinii, Poa angustifolia.

Constant species: Achillea millefolium, Bromus squarrosus, Cardaria draba, Cichorium intybus, Consolida paniculata, Elytrigia repens, Eryngium campestre, Festuca valesiaca, Galium humifusum, Plantago lanceolata, Poa bulbosa, Tragopogon dubius.

Dominant species: Artemisia santonicum, Elytrigia repens, Festuca valesiaca.

This association was described by Tyshchenko (2000) for Stepok island (loess part of Fedotova Spit), located in the Northern Pryazov'ya. It was included in the Festucion valesiacae alliance, but, in our opinion, it should be considered in the alliance Artemisio tauricae-Festucion valesiacae because it is characterized by a number of halophilic species: Artemisia santonicum, Elytrigia elongata, Artemisia taurica, Camphorosma monspeliaca and others. These communities are distributed in Prysyvashshia, the Crimea, and Pryazov'ya (Figure 3). They are related to alkaline loam ecotopes of the coastline. Total cover of these communities is about $70-80 \%$. The accumulative richness in the communities of the association sums up to 132 vascular plant species.
Association B2. Agropyro pectinati-Artemisietum tauricae ass. nov. hoc loco (Holotypus: Table 3, relevé 1; Location: Ukraine, Zaporizhzhia region, Yakymivsky district, neighbourhood of Atmanay village, 19. 07. 2005).

Diagnostic species: Artemisia santonicum, Artemisia taurica, Cardaria draba, Consolida paniculata, Ferula euxina, Limonium gmelinii.

Constant species: Achillea millefolium, Agropyron pectinatum, Bromus squarrosus, Centaurea diffusa, Elytrigia repens, Eryngium campestre, Falcaria vulgaris, Festuca valesiaca, Galium humifusum, Plantago lanceolata, Poa angustifolia, Poa bulbosa, Salvia nemorosa, Tragopogon dubius.

Dominant species: Artemisia taurica, Elytrigia repens, Festuca valesiaca.

This association combines desert-steppe communities on chestnut (loam) soils dominated by Festuca valesiaca, Elytrigia repens and Artemisia taurica that occur mostly on upper part of the slopes (Figure 5). Such communities in the study area were referred to Ferulo orientalisArtemisietum tauricae Korzhenevskij \& Kljukin 1991 by Dubyna \& Dziuba (2007). However, the floristic composition of these communities is quite different from the original ones described by Korzhenevskij \& Kljukin (1991) for mud volcanoes of the Kerch peninsula. Thus, we describe a new association which combines these communities. They are distributed in Prysyvashshia on Kerch and Taman peninsulas within the study area (Figure 3) characterised by a relatively high total cover of vegetation (65-90\%). The accumulative richness in the communi-

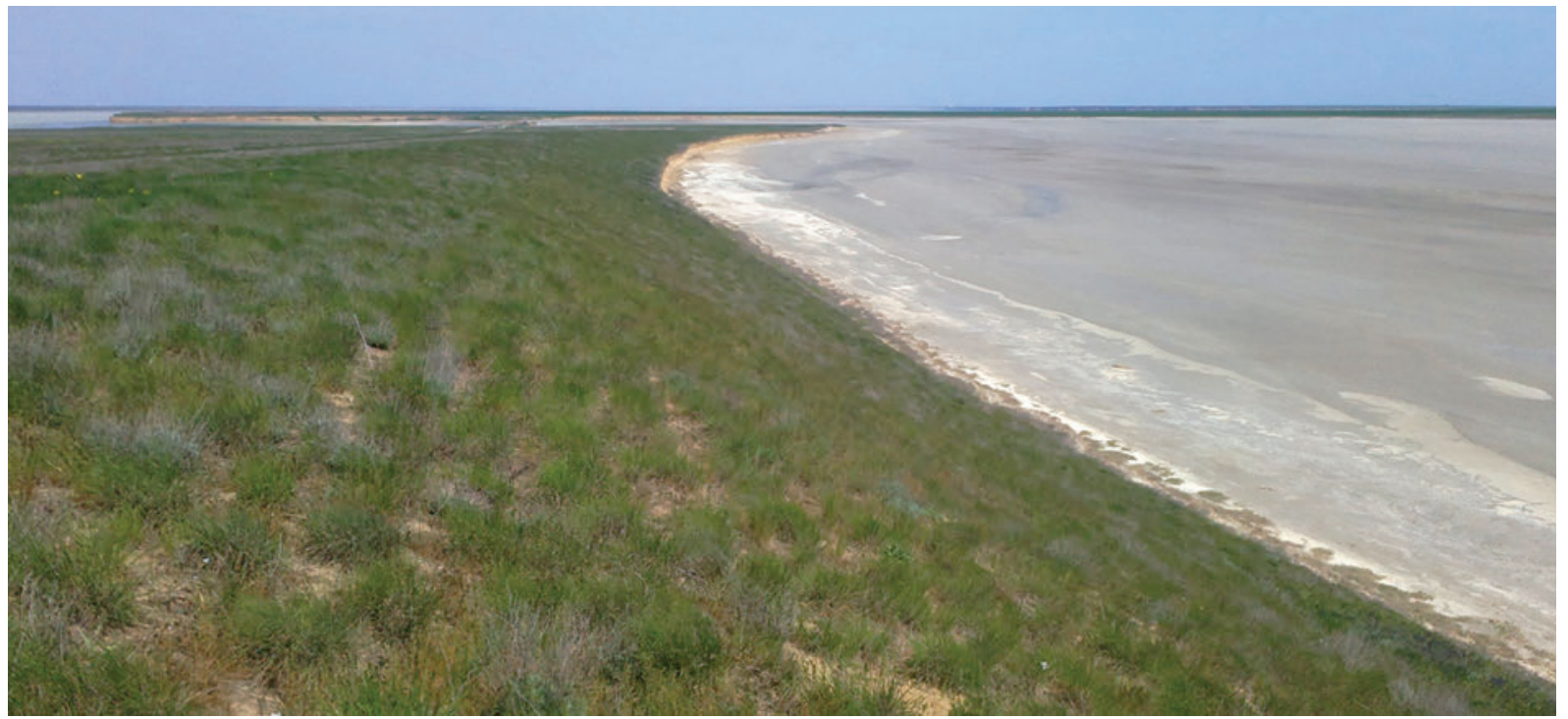

Figure 5: Agropyro pectinati-Artemisietum tauricae (B2), Ukraine, Kherson region, Genichesky district, Kuyuk-Tuk Island, Azov-Syvash National Park, 18.04.2014 (Photo: D. Vynokurov).

Slika 5: Agropyro pectinati-Artemisietum tauricae (B2), Ukrajina, območje Kherson, okrožje Genichesky, otok Kuyuk-Tuk, narodni park AzovSyvash, 18.04.2014 (foto: D. Vynokurov). 
ties of the association sums up to 132 vascular plant species. Therefore, this association distinguishes itself by a poor floristic diversity, similar to the previous one. The reason for this being the limiting factor of salinity.

Association B3. Cerastio syvashici-Poetum bulbosae ass. nov. hoc loco (Holotypus: Table 3, relevé 12; Location: Ukraine, Kherson region, Novotroitsky district, south suburbs of Druzhelyubovka village, Kutara Cape, 09. 05. 2003).

Diagnostic species: Caroxylon laricinum, Cerastium syvaschicum, Erodium ciconium, Galium tenuissimum, Lamium amplexicaule, Lepidium perfoliatum, Leymus ramosus, Linaria macroura, Ornithogalum kochii, Prangos odontalgica, Taraxacum erythrospermum, Trifolium arvense, Vicia tetrasperma, Viola kitaibeliana.

Constant species: Agropyron pectinatum, Artemisia austriaca, Carduus uncinatus, Crepis tectorum, Elytrigia repens, Falcaria vulgaris, Festuca valesiaca, Galatella villosa, Kochia prostrata, Phlomis pungens, Poa bulbosa, Salvia aethiopis, Senecio vernalis, Stipa capillata.

Dominant species: Agropyron pectinatum, Festuca valesiaca. This association combines transitional communities from saline-steppes to real steppes which are spread on the upper slopes of the coastal zone. The distribution of these coenoses ranges as far as Prysyvashshia (Figure 3). In comparison to the other communities of the alliance, they are characterised by the lowest number of species indicative for saline steppes. Most of them are presented by Leymus ramo- sus, Caroxylon larinicum, Cerastium syvaschium, Artemisia taurica, etc. Conversely, they are characterised by the highest number of true steppe species - Prangos odontalgica, Artemisia austriaca, Falcaria vulgaris, Galatella villosa, Phlomis pungens, Stipa capillata, S. ucrainica and others. The significant number of ephemeral plants and ephemeroids (Cerastium syvaschicum, Poa bulbosa, Myosotis micrantha, Lamium amplexicaule, Ornithogalum kochii, Tulipa gesneriana, Bellevalia sarmatica) is a characteristic feature of the sagebrush steppes (Figure 6). The accumulative richness in the communities of the association sums up to 205 vascular plant species. The average total vegetation cover is $70 \%$.

The alliance Tanaceto millefolii-Galatellion villosae $\mathrm{Vy}$ nokurov all. nov. hoc loco (Holotypus: Ephedro distachyae-Stipetum capillatae Kolomiychuk et Vynokurov 2016 (see below), Table 4, relevés 21-40) includes the vegetation of bunchgrass steppes. Diagnostic species: Agropyron pectinatum, Alyssum hirsutum, Dianthus elongatus, Dichodon viscidum, Ephedra distachya, Galatella villosa, Pleconax subconica, Tanacetum millefolium.

According to our preliminary data (Kolomiychuk \& Vynokurov 2014), communities of Tanaceto millefoliiGalatellion villosae are distributed in the bunchgrass steppe subzone of Ukraine (according Barbarych 1977), which stretches from the Danube estuary in the west to Taganrog Bay in the east. In the North it is replaced by Stipo lessingianae-Salvion nutantis (forb-bunchgrass steppes). We distinguish between four associations of the alliance and four subassociations in the study area.

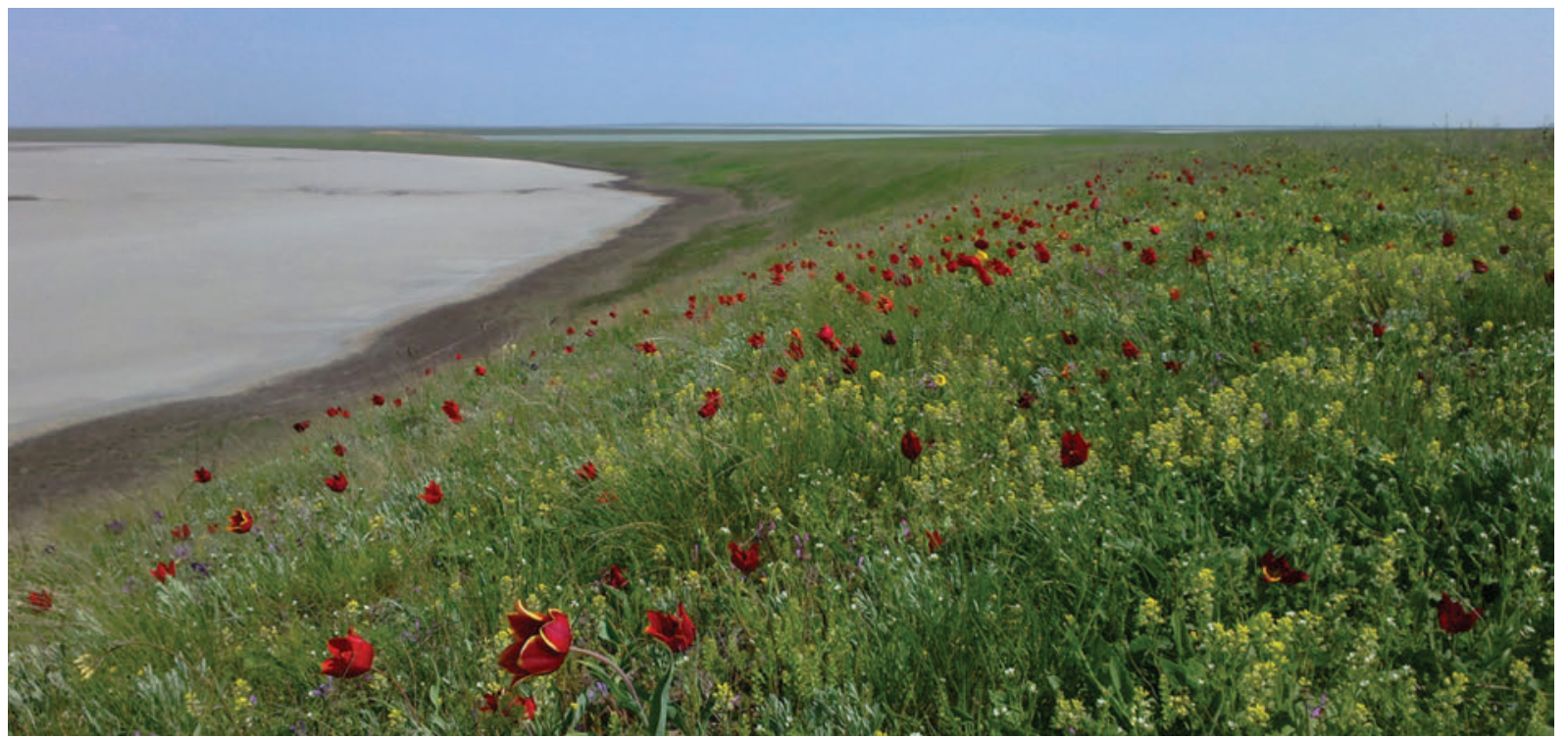

Figure 6: Cerastio syvashici-Poetum bulbosae (B3), Ukraine, Kherson region, Novotroitsky district, Churiuk Island, Azov-Syvash National Park, 18.04.2014 (Photo: D. Vynokurov).

Slika 6: Cerastio syvashici-Poetum bulbosae (B3), Ukrajina, območje Kherson, okrožje Novotroitsky, otok Churiuk, narodni park Azov-Syvash, 18.04.2014 (foto: D. Vynokurov) 
Association C1. Stipo brauneri-Bromopsidetum cappadocicae ass. nov. hoc loco (Holotypus: Table 4, relevé 6; Location: Ukraine, Autonomous Republic of Crimea, Leninsky district, the eastern neighbourhood of Hlazovka village, Shyroka Balka stow, slope to the Kerch strait, 18. 09. 2010).

Diagnostic species: Dactylis glomerata, Orchis picta, Ornithogalum flavescens, Plantago lanceolata, Scorzonera mollis, Stipa brauneri, Teucrium chamaedrys.

Constant species: Agropyron pectinatum, Artemisia taurica, Bromus squarrosus, Carduus uncinatus, Centaurea diffusa, Dianthus elongatus, Elytrigia repens, Eryngium campestre, Euphorbia seguieriana, Falcaria vulgaris, Festuca valesiaca, Galatella villosa, Galium verum, Jurinea mollis, Koeleria cristata, Linum perenne, Phlomis pungens, Poa bulbosa, Potentilla recta, Salvia nemorosa, Securigera varia, Silene otites aggr.

Dominant species: Festuca valesiaca, Galatella villosa.

This association combines communities on black soils, which cover Pontic and Meiotic limestones the Pliocene. These coenoses are distributed on slopes facing various directions on the Kerch Peninsula (Figure 4). They can be described as an intermediate type of limestone vegetation community . Total vegetation cover is approximately $70 \%$. The accumulative richness in the communities of the association sums up to 241 vascular plant species.

Subassociation C1a. Stipo brauneri-Bromopsidetum cappadocicae typicum subass. nov. hoc loco (Holotypus, diagnostic species: identical with the type of the association) (Figure 7).

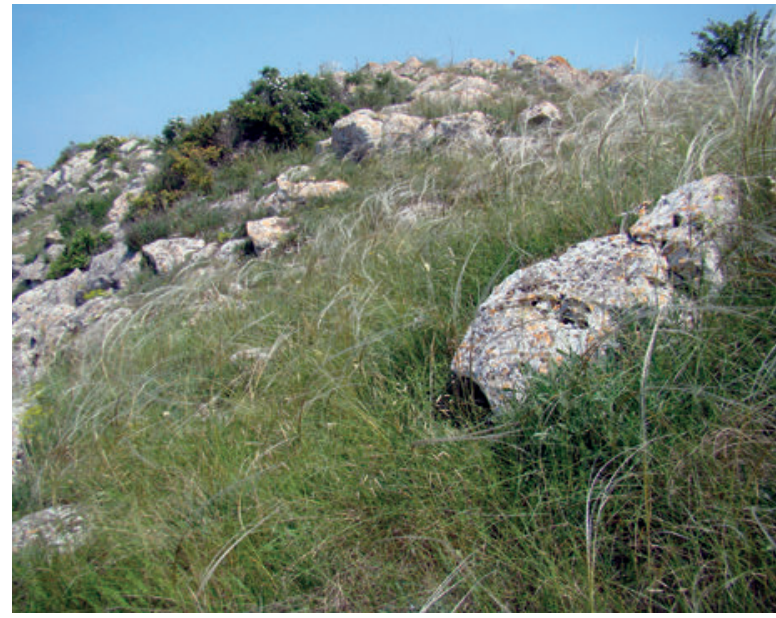

Figure 7: Stipo brauneri-Bromopsidetum cappadocicae typicum (C1a), Ukraine, Crimea, Leninsky district, east of Zolote village, Karalarsky Regional Landscape Park, Shovkovytseva bay, 28. 05. 2010 (Photo: V. Kolomiychuk).

Slika 7: Stipo brauneri-Bromopsidetum cappadocicae typicum (C1a), Ukrajina, Krim, okrožje Leninsky, vzhodno od vasi Zolote, regionalni krajinski park Karalarsky, zaliv Shovkovytseva, 28. 05. 2010 (foto: V. Kolomiychuk).
Subassociation C1b. Stipo brauneri-Bromopsidetum cappadocicae jurineetosum stoechadifoliae subass. nov. hoc loco (Holotypus: Table 4, relevé 18; Location: Ukraine, Autonomous Republic of Crimea, Leninsky district, between Kamyanske and Zavods'ke villages, steppe slope to Arabatska Bay, 08. 06. 2009).

Diagnostic species: Alyssum tortuosum, Artemisia lerchiana, Astragalus pubiflorus, Bromopsis cappadocica, Dianthus capitatus, Ephedra distachya, Jurinea stoechadifolia, Koeleria cristata, Scorzonera mollis, Stipa brauneri, Veronica verna.

Constant species: Agropyron pectinatum, Bromus squarrosus, Centaurea diffusa, Cephalaria uralensis, Eryngium campestre, Euphorbia seguieriana, Festuca valesiaca, Galatella villosa, Galium verum, Kochia prostrata, Linum perenne, Medicago falcata aggr., Phlomis pungens, Pleconax subconica, Potentilla recta, Silene otites aggr., Teucrium polium, Veronica triphyllos.

In contrast to the previous subassociation, the communities of the subassociation Stipo brauneri-Bromopsidetum cappadocicae jurineetosum stoechadifoliae are formed on steeper slopes of limestone, and are characterized by more sparse vegetation (50-60\%). Just as communities of the previous subassociation, they are distributed exclusively on the Kerch Peninsula (Figure 4). The accumulative richness in the communities of the association amounts to 213 vascular plant species.

Association C2. Ephedro distachyae-Stipetum capillatae ass. nov. hoc loco (Holotypus: Table 4, relevé 21; Location: Ukraine, Zaporizhzhia region, Yakymivsky district, neighbourhood of Bogatyr village, steppe slope to Molochny estuary, 28. 05. 2008).

Diagnostic species: Linaria genistifolia, Stipa capillata.

Constant species: Agropyron pectinatum, Arenaria serpyllifolia, Bromopsis riparia, Carduus uncinatus, Elytrigia repens, Ephedra distachya, Eryngium campestre, Euphorbia seguieriana, Falcaria vulgaris, Festuca valesiaca, Galatella villosa, Goniolimon tataricum, Koeleria cristata, Medicago falcata aggr., Poa bulbosa, Potentilla recta, Salvia nemorosa, Salvia nutans, Seseli tortuosum, Silene otites aggr., Tanacetum millefolium, Teucrium polium, Thalictrum minus, Xeranthemum annuum.

Dominant species: Festuca valesiaca, Stipa capillata.

The communities of this association are most advanced of xerosere succession in the region. It is the central association of the alliance, and, accordingly, its distribution area matches with the area of Tanaceto millefoliiGalatellion villosae. In the coastal zone of the Sea of Azov these grasslands are mainly to be found on the uplands and upper gentle slopes. They are commonly distributed in North and Crimean Pryazov'ya (Figure 4). The accu- 
mulative richness in the communities of the association amounts to 260 vascular plant species. Total vegetation cover is on average $60-70 \%$.

Subassociation C2a. Ephedro distachyae-Stipetum capillatae typicum subass. nov. hoc loco (Holotypus, diagnostic species: identical with the type of the association) (Figure 8).

Subassociation C2b. Ephedro distachyae-Stipetum capillatae helichrysetosum arenarii subass. nov. hoc loco (Holotypus: Table 4, relevé 32; Location: Ukraine, Zaporizhzhia region, Yakymivsky district, neighbourhood of Bogatyr village, steppe slope to Molochny estuary, 27. 05. 2008).

Diagnostic species: Achillea leptophylla, Artemisia austriaca, Asparagus officinalis, Astragalus varius, Echinops ruthenicus, Ephedra distachya, Helichrysum arenarium, Herniaria besseri, Jurinea multiflora, Kochia prostrata, Limonium sareptanum, Polycnemum arvense, Polygonum aviculare, Thymus $x$ dimorphus, Tragopogon dasyrhynchus.
Constant species: Agropyron pectinatum, Alyssum hirsutum, Eryngium campestre, Euphorbia seguieriana, Falcaria vulgaris, Festuca valesiaca, Galatella villosa, Galium verum, Goniolimon tataricum, Medicago falcata, Poa bulbosa, Potentilla recta, Stipa capillata, Stipa lessingiana, Tanacetum millefolium, Verbascum phoeniceum.

Dominant species: Agropyron pectinatum, Festuca valesiaca, Stipa capillata.

This subassociation comprises pontic hemipsammophytic bunchgrass steppes. They are not widely spread within the observed region and mainly concentrate on the slopes of Molochny estuary, in the Zaporizhzhia region (Figure 4). Next the coastline of the Sea of Azov, such coenoses are distributed in the old estuary of the Dnieper River. The communities form on sandy soils, so they include psammophytic species: Helichrysum arenarium, Astragalus varius, Echinops ruthenicus and Achillea leptophylla. The accumulative richness in the communities of the association sums up to 159 vascular plant species. The total cover of vegetation is $70-90 \%$.

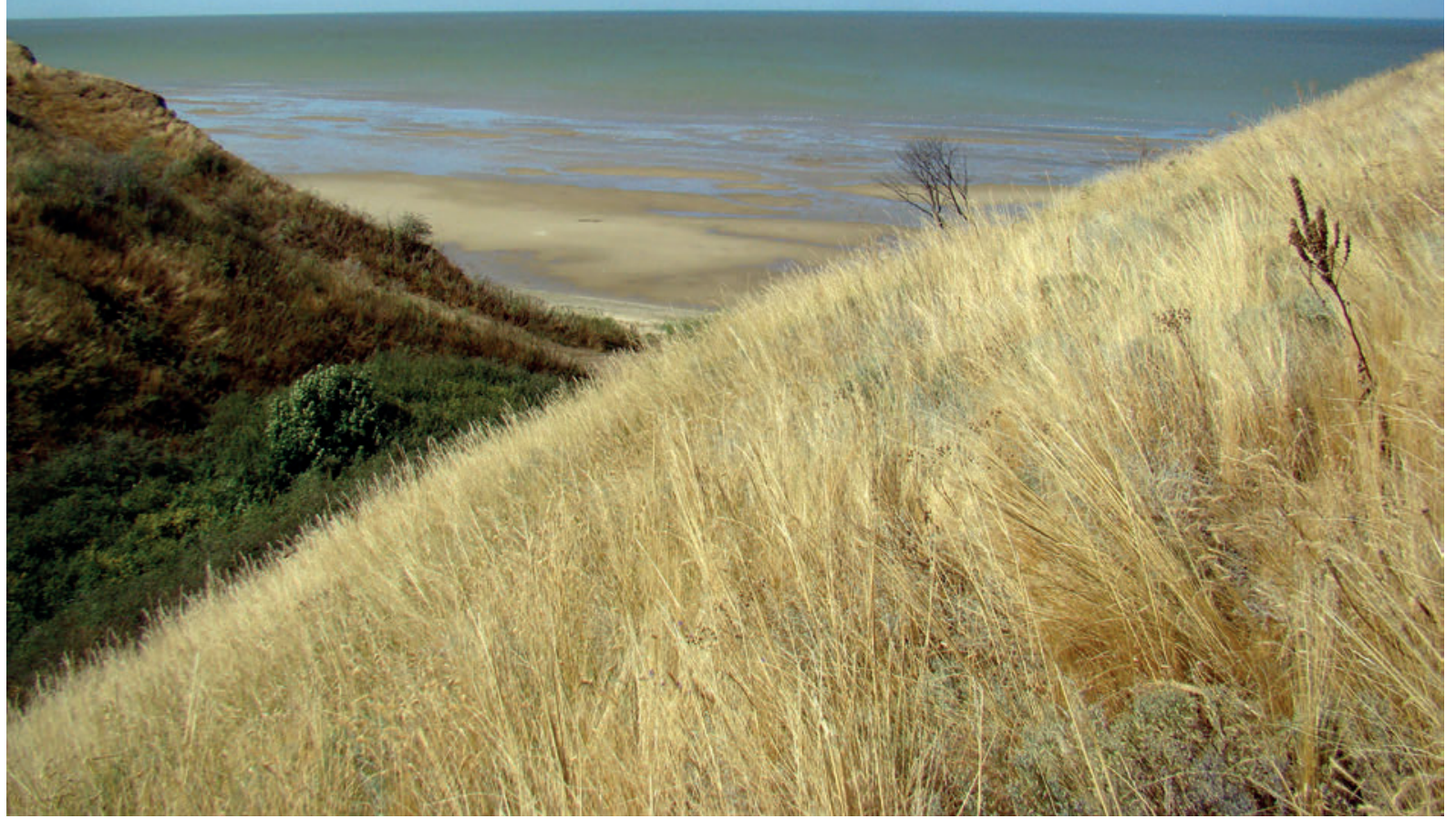

Figure 8: Ephedro distachyae-Stipetum capillatae typicum (C2a), Russian Federation, Rostov region, Azovsky district, west of Semibalky village, steppe slope to the Taganrog bay, 15.09.2010 (Photo: V. Kolomiychuk).

Slika 8: Ephedro distachyae-Stipetum capillatae typicum (C2a), Ruska federacija, regija Rostov, okrožje Azovsky, zahodno od vasi Semibalky, stepsko vznožje do zaliva Taganrog, 15.09.2010 (foto: V. Kolomiychuk). 
Association C3. Tanaceto millefolii-Salvietum nemorosae Diagnostic species: Bromopsis riparia, Securigera varia, Tanacetum millefolium.

Constant species: Agropyron pectinatum, Alyssum hirsutum, Artemisia austriaca, Bromus squarrosus, Carduus uncinatus, Elytrigia repens, Eryngium campestre, Euphorbia seguieriana, Falcaria vulgaris, Festuca valesiaca, Galatella villosa, Kochia prostrata, Koeleria cristata, Medicago falcata, Phlomis pungens, Poa bulbosa, Salvia nemorosa, Silene otites aggr.

Dominant species: Festuca valesiaca.

This association represents disturbed communities as a result of overgrazing. They are in the intermediate stages of pasture degradation. Reducing or ceasing the disturbance factors allows communities to restore and change into the association Ephedro distachyae-Stipetum capillatae. In the coastal zone of the Sea of Azov, they are widespread (Northern, Eastern Pryazov'ya, and Prysyvashshia) and occupy uplands and retreating slopes (Figure 4). The accumulative richness in the communities of the association sums up to 234 vascular plant species. The average cover is $70 \%$.

Association C4. Stipo ucrainicae-Agropyretum pectinati Diagnostic species: Serratula erucifolia, Stipa ucrainica. Constant species: Agropyron pectinatum, Artemisia austriaca, Buglossoides arvensis, Carduus uncinatus, Crepis tectorum, Cruciata pedemontana, Elytrigia repens, Euphorbia seguieriana, Falcaria vulgaris, Festuca valesiaca, Galatella villosa, Goniolimon tataricum, Iris pumila, Kochia prostrata, Lamium amplexicaule, Lepidium perfoliatum, Pastinaca clausii, Phlomis pungens, Poa bulbosa, Scorzonera mollis, Stipa capillata, Tulipa gesneriana, Verbascum densiflorum, Viola kitaibeliana.

Dominant species: Agropyron pectinatum, Elytrigia repens, Festuca valesiaca, Galatella villosa, Stipa ucrainica.

The communities of this association occupy an intermediate position along the salinity gradient between associations Cerastio syvashici-Poetum bulbosae and Ephedro distachyae-Stipetum capillatae. They are distributed in Northern and Eastern Crimean Pryazov'ya and Prysyvashshia (Figure 4). They occur on medium steep slopes of the coastline. In the study area they do not cover large areas because of ploughing of surrounding upland ecotopes. The accumulative richness in the communities of the association sums up to 122 vascular plant species. The average cover is $70-75 \%$.

The alliance Stipo lessingianae-Salvion nutantis includes vegetation of forb-bunchgrass steppes (Vynokurov $2014 \mathrm{~b})$. Its distribution roughly coincides with that of forb-bunchgrass steppe subzone of Ukraine (Barbarych 1977). It is marked by the presence of forbs less common for bunchgrass subzone (Stachys recta, Asperula cynanchica, Marrubium praecox, Seseli tortuosum, Potentilla recta, Phlomis pungens, Astragalus onobrychis). In the examined area, communities of the alliance are spread along the coast of the Taganrog Bay and in the Russian part of the Sea of Azov (Rostov region, Krasnodar territory).

Association H1. Stipo lessingianae-Salvietum nutantis Diagnostic species: Asperula cynanchica, Medicago falcata, Salvia nutans, Stachys recta, Stipa lessingiana.

Constant species: Achillea millefolium, Artemisia austriaca, Astragalus onobrychis, Bromopsis riparia, Dianthus elongatus, Elytrigia intermedia, Elytrigia repens, Ephedra distachya, Euphorbia seguieriana, Falcaria vulgaris, Festuca valesiaca, Galatella villosa, Galium verum, Glycyrrhiza glabra, Kochia prostrata, Koeleria cristata, Linum perenne, Phlomis pungens, Poa angustifolia, Potentilla recta, Salvia nemorosa, Securigera varia, Seseli tortuosum, Stipa capillata, Tanacetum millefolium, Teucrium polium.

Dominant species: Festuca valesiaca, Stipa lessingiana.

This association takes up the central position of the alliance. The presence of these communities at the coast of the Sea of Azov was described by Demina (2012), who included them in Stipetum lessingianae Soó 1949. But, cluster analysis separated relevés from Azov and original relevés from Transilvania in different alliances (Soó 1949). Thus, we propose to include them in Stipo lessingianae-Salvietum nutantis described in the forb-bunchgrass steppe zone (Vynokurov 2014b). These communities cover upland areas and gentle slopes. They are not widely spread in the area (distributed in Northern, Eastern and Don Pryazov'ya, Figure 3), but they are characterised by the richest floristic diversity of all the identified associations at plot level. The accumulative richness in the communities of the association sums up to 104 vascular plant species. The average total vegetation cover is $75-80 \%$.

In the following, we present a syntaxonomic scheme indicating the most used synonyms and specification of type syntaxa.

\section{Class Festuco-Brometea Br.-Bl. \& Tx. ex Klika \& Hadač 1944}

Typus: Brometalia erecti W. Koch 1926

Syn.: Festuco-Brometea Br.-Bl. \& Tx. 1943 nom. inval. (Art. 8), Festuco-Brometea Br.-Bl. \& Tx. ex Soó 1947 nom. illeg. (Art. 31)

Order Galatello villosae-Stipetalia lessingianae $\mathrm{Vy}$ nokurov ord. nov. prov.

Typus: Stipo lessingianae-Salvion nutantis Vynokurov 2014 Syn.: Carici praecoxi-Elytrigietalia pseudocaesiae Solomakha et al. 2005 nom. inv. (Art. 5) p.p. 
Alliance A. Artemisio-Kochion prostratae Soó 1964 Typus: Agrogyro cristati-Kochietum prostratae Zólyomi 1958

Syn.: Artemisio-Kochion Soó 1959 prov. (art. 3b), Agropyro-Kochion Soó 1971 (fantom)

Association A1. Goniolimono taurici-Poetum angustifoliae Tyshchenko 1996

Typus: relevé 2, table 2 in Tyshchenko 1996, p. 69

Alliance B. Artemisio tauricae-Festucion valesiacae Korzhenevskij et Kljukin 1991

Typus: Ferulo orientalis-Artemisietum tauricae Korzhenevskij et Kljukin 1991

Association B1. Ferulo orientalis-Agropyretum pectinati Tyshchenko 2000

Typus: relevé 2, table 2 in Tyshchenko 2000, p. 90

Association B2. Agropyro pectinati-Artemisietum tauricae Kolomiychuk et Vynokurov 2016 (this paper) Typus: relevé 1 , table 3 (this paper)

Association B3. Cerastio syvashici-Poetum bulbosae

Kolomiychuk et Vynokurov 2016 (this paper)

Typus: relevé 12 , table 3 (this paper)

Alliance C. Tanaceto millefolii-Galatellion villosae Vynokurov in Kolomiychuk et Vynokurov 2016 (this paper)

Typus: Ephedro distachyae-Stipetum capillatae Kolomiychuk et Vynokurov 2016 (this paper)

Syn.: Poo angustifoliae-Ferulion orientale Solomakha et al. 2005 nom. inv. (Art. 5) p.p.

Association C1. Stipo brauneri-Bromopsidetum capadocicae Kolomiychuk et Vynokurov 2016 (this paper) Typus: relevé 6 , table 4 (this paper)

Subassociation C1a. Stipo brauneri-Bromopsidetum cappadocicae typicum Kolomiychuk et Vynokurov 2016 (this paper)

Typus: relevé 6 , table 4 (this paper)

Subassociation C1b. Stipo brauneri-Bromopsidetum cappadocicae jurineetosum stoechadifoliae Kolomiychuk et Vynokurov 2016 (this paper)

Typus: relevé 18 , table 4 (this paper)

Association C2. Ephedro distachyae-Stipetum capillatae Kolomiychuk et Vynokurov 2016 (this paper)

Typus: relevé 21, table 4 (this paper)

Subassociation C2a. Ephedro distachyae-Stipetum capillatae typicum Kolomiychuk et Vynokurov 2016 (this paper)

Typus: relevé 21, table 4 (this paper)

Subassociation C2b. Ephedro distachyae-Stipetum capillatae helichrysetosum arenarii Kolomiychuk et Vynokurov 2016 (this paper)

Typus: relevé 32, table 4 (this paper)

Association C3. Tanaceto millefolii-Salvietum nemorosae Krasova et Smetana 1999
Typus: Krasova \& Smetana 1999, p. 27

Syn.: Crinitarietum villosae Krasova et Smetana 1999, Bromopsidi ripariae-Plantagetum lanceolatae Smetana 2002 nom. inv. (art. 5) p.p.

Association C4. Stipo ucrainicae-Agropyretum pectinati Tyschenko 1996

Typus: relevé 6, table 2 in Tyshchenko 1996, p. 69

Alliance H. Stipo lessingianae-Salvion nutantis Vynokurov 2014

Typus: Stipo lessingianae-Salvietum nutantis Vynokurov 2014

Syn.: Astragalo-Stipion Knapp 1944 sensu auct. ukr., Phlomenion pungentis Saitov et Mirkin 1991 nom. inv. (art. 2a), Chamaecytision ruthenici Smetana 2002 nom. inv. (art. 5), Poo angustifoliae-Stipion capillatae Goncharenko 2003 nom. inv. (art. 5)

Association H1. Stipo lessingianae-Salvietum nutantis Vynokurov 2014

Typus: relevé 21, table 2 in Vynokurov 2014b, p. 543. Syn.: Stipetum lessingianae sensu auct. ukr. non Soó 1949.

\section{Conclusions}

The vegetational class of Festuco-Brometea of the Sea of Azov coastal zone comprises four alliances. Whether steppe communities are transformed as a result of natural or by anthropogenic factors, they are related to the alliance Artemisio-Kochion prostratae. They are characterised by a significant number of synanthropic species. The vegetation of saline steppes or desert steppes is classified in the alliance Artemisio tauricae-Festucion valesiacae. In this alliance we distinguish three associations, two of which we propose as new ones. The vegetation of bunchgrass steppes, which is marked by a powerful block of diagnostic species, did not meet any currently known syntaxonomical unit. Therefore, we describe a new alliance Tanaceto millefolii-Galatellion villosae. It features great coenotic diversity and includes four associations and four subassociations. In our study area, the vegetation of forb-bunchgrass steppes is rerpresented by one association which was ordered to alliance Stipo lessingianae-Salvion nutantis.

The loess and limestone coasts of the Sea of Azov have been subject to constant and heavy erosion, which is aggravated by currently rising sea levels caused by global climate change. Key factors accelerating coastal erosion processes are the lack of coastal protection strategies, the destruction of accumulative forms that protect abrasion coasts, persistent violations of environmental and water legislation (i.e. construction projects in the protective coastal belt, soil cultivation close to the cliffs). The 
combined impacts of the abovementioned factors lead to increasing incidents of landslides in the coastal area. As a result, steppe ecosystems are lost or replaced by synanthropic ones. Moreover, the flora of the coastal zone of the Sea of Azov loses its natural makeup while it is more and more anthropogenically influenced.

\section{References}

Barbarych, A.I. (ed.) 1977: Geobotanical zoning of Ukrainian SSR. Naukova Dumka, Kyiv, 304 pp [in Ukrainian].

Bilyk, G. I. 1973: Desert steppe vegetation. In: Barbarych, A.I. (ed.): The vegetation of USSR. Steppes, rocky outcrops, sands. Naukova Dumka, Kyiv, pp. 229-245 [in Ukrainian].

Bohn, U., Neuhäusl, R., Gollub, G., Hettwer, C., Neuhäuslová, Z., Raus, T., Schlüter, H. \& Weber, H. 2004: Map of the Natural Vegetation of Europe scale 1: 2500 000. Münster, Landwirtschaftsverlag.

Braun-Blanquet, J. 1964: Pflanzensoziologie. Grundzuge der Vegetationskunde. 3 Aufl. Springer-Verlag, Wien-New York, 865 pp.

Chytrý, M., Hennekens, S. M., Jiménez-Alfaro, B., Knollová, I., Dengler, J., Jansen, F., Landucci, F., Schaminée, J. H. J., Aćić, S., (...) \& Yamalov, S. 2016: European Vegetation Archive (EVA): an integrated database of European vegetation plots. Applied Vegetation Science 19: 173-180.

Chytrý, M., Tichý, L., Holt, J. \& Botta-Dukát, Z. 2002:

Determination of diagnostic species with statistical fidelity measures. Journal of Vegetation Science 13: 79-90.

Dembicz, I., Moysiyenko, I. I., Shaposhnikova, A., Vynokurov, D., Kozub, L. \& Sudnik-Wójcikowska, B. 2016: Isolation and patch size drive specialist plant species density within steppe islands: a case study of kurgans in southern Ukraine. Biodiversity and Conservation. DOI:10.1007/s10531-016-1077-y.

Demina, O. N. 2012: East Black Sea forb-bunchgrass steppes of the Don River basin (within Rostov region). Vegetation of Russia 20: 27-47 (in Russian).

Didukh, Ya. P. \& Shelyag-Sosonko, Yy. R. 2003: Geobotanical zoning of Ukraine and adjacent territories. Ukrainian Botanical Journal 60 (1): 6-17 [in Ukrainian].

Dúbravková, D. \& Koštál, J. 2012: Acidophilous Dry Grasslands on the Quartzite Bedrock in Western Slovakia. Hacquetia 11(2): 249-269.

Dúbravková-Michálková, D., Janišová, M., Kolbek, J., Šuvada, R., Virók, V. \& Zaliberová, M. 2008: Dry Grasslands in the Slovenský Kras MTS (Slovakia) and the Aggteleki-karszt MTS (Hungary) - A Comparison of Two Classification Approaches. Hacquetia 7(2): 123-140.

Dubyna, D. V. \& Dziuba, T. P. 2007: Syntaxonomy of Island's vegetation of the Azovo-Syvaskiy National Nature Park. Classes: Festuco-Brometea, Agropyretea repentis, Chenopodietea, Artemisietea vulgaris. Chornomorski Botanical Journal 3(1): 30-43 [in Ukrainian].
Foggi, B., Lastrucci, L. Gennai, M. \& Viciani, D. 2014: The FestucoBrometea grasslands on sandstone and marl-clay-sandstone substrata in Tuscany (Northern-Central Italy). Hacquetia 13(1): 19-54.

Grechushkina, N. A., Sorokin, A. N. \& Golub, V. B. 2012: Plant communities of the class Festuco-Brometea Br.-Bl. et Tx. ex Soó 1947 on the Azov Sea coast of Russia. In: Galiev, R.S. \& Rukhlenko, I.A. (eds.) Proceedings of the IX International scientific-practical conference "Tatishchev read: actual problems of science and practice. Actual problems of ecology and environmental protection", Togliatti, pp. 50-56 [in Russian].

Hennekens, S. M. \& Schaminée, J. H. 2001: TURBOVEG, a comprehensive data base management system for vegetation data. Journal of Vegetation Science 12: 589-591.

Kaplin, P. A., Leontiev, O. K., Lukyanova, S. A. \& Nikiforov, L. G. 1991: Shores. Mysl, Moscow, 480 pp. [in Russian].

Kolomiychuk, V. P. \& Vynokurov, D. S. 2014: Previous prodromus of the steppe vegetation of class Festuco-Brometea on the coastal zone of the Azov Sea in Ukraine and Russia. In: Lukash, A.V., Karpenko, Yu.A. \& Kirienko, S.V. (eds.), Priorities scientific value of protected areas of Polesie: Materials of International scientific and practical workshop, Chernihiv, pp. 41-44 [in Ukrainian].

Korotchenko, I. A. \& Peregrym, M. M. 2012: Ukrainian steppes in the past, at present and in the future. Eurasian Steppes. Ecological Problems and Livelihoods in a Changing World. Plant and Vegetation 6: 173-196.

Korzhenevskij, V. V. \& Kljukin, A. A. 1986: Phytoindication of relief of uplands in the Kerch peninsula, taking Kazantip peninsula as an example. Bulletin of the State Nikita Botanical Gardens 98: 111-122 [in Russian].

Korzhenevskij, V. V. \& Kljukin, A. A. 1991: Vegetation description of mud volcanoes of Crimea. Feddes Repertorium 102 (1-2): $137-150$.

Korzhenevskij, V. V., Bagrikova, N. A., Ryff, L. E. \& Levon, A. R. 2003: Prodromus of vegetation of Crimea (20 years on the platform of floristic classification). Bulletin of the State Nikita Botanical Gardens 186: 32-63 [in Russian].

Kostyliov, O. V., Movchan, Ya. I., Osychniuk, V. V. \& Solomakha, V. A. 1984: Main associations of the steppe vegetation in the "Khomutovsky steppe" reserve. Ukrainian Botanical Journal 41 (6): 12-17 [in Ukrainian].

Krasova O. O. \& Smetana M. G. 1999: Steppe vegetation of the "Kobylna" gully. Ukrainian Phytosociological Collection, Series A, Phytosociology 1-2 (12-13): 21-31 [in Ukrainian].

Matishov, G. G., Golubeva, N. I. \& Sorokina, V. V. 2011: Ecological atlas of the Sea of Azov. SSC RAS Publishers, Rostov-on-Don, 328 pp. [in Russian].

Mosyakin, S. L. \& Fedoronchuk, M. M. 1999: Vascular plants of Ukraine. A nomenclatural checklist. Specialized printing house of scientific journals of the NAS of Ukraine, Kyiv, 345 pp.

Roleček, J., Tichý, L., Zelený, D. \& Chytrý, M. 2009: Modified TWINSPAN classification in which the hierarchy respects cluster heterogeneity. Journal of Vegetation Science 20: 596-602. 
Shnyukov, E. F., Orlovsky, G. N. \& Usenko, V. P. 1974: Geology of the Sea of Azov. Naukova Dumka, Kyiv, 247 pp. [in Russian].

Solomakha, V. A. 2008: The syntaxonomy of vegetation of the Ukraine. The third approximation. Phytosociocentre, Kyiv, 296 pp. [in Ukrainian].

Soó, R. 1949: Les associations vegetales de la Moyenne-Transylvanie II. Les associations des marais, des prairies et des steppes. Acta Geobotanica Hungarica 6: 3-107.

Sopotlieva, D. \& Apostolova, I. 2014: Dry grassland vegetation in the transition zone between two Biogeographic Regions. Hacquetia 13(1): 79-120.

Tichý, L. 2002: JUICE, software for vegetation classification. Journal of Vegetation Science 13: 451-453.

Tyshchenko, O. V. 1996: Steppe and psammophytic-steppe vegetation of the "Obitochna Kosa" Reserve. Ukrainian Phytosociological Collection. Series A Phytosociology 2 (2): 63-72 [in Ukrainian].

Tyshchenko, O. V. 1998: The vegetation of Kryva Spit (Donetsk region) of the northern coast of the Sea of Azov and peculiarities of its dynamics. Ukrainian Phytosociological Collection. Series A Phytosociology 2 (11): 26-42 [in Ukrainian].

Tyshchenko, O. V. 1998: The vegetation of Samsonova and Bezimenna Spits of the northern coast of the Sea of Azov (Donetsk region) and peculiarities of its dynamics. Ukrainian Phytosociological Collection. Series A Phytosociology 1 (9): 60-77 [in Ukrainian].

Tyshchenko, O. V. 2000: New syntaxons of the nothern Azov Sea coast spits vegetation. Ukrainian Phytosociological Collection. Series A Phytosociology 1 (16): 89-93.
Tyshchenko, O. V. 2006: Vegetation of coastal spits of the Northern coast of the Azov Sea. Phytosociocentre, Kyiv, 156 pp. [in Ukrainian].

Vassilev, K., Apostolova, I. \& Pedashenko, H. 2012: Festuco-Brometea in Western Bulgaria with an emphasis on Cirsio-Brachypodion pinnati. Hacquetia 11(2): 227-248.

Vynokurov, D. S. 2014a: Syntaxonomy of xerothermic vegetation of the Ingul river valley (Class Festuco-Brometea). Part 1. Petrophytic steppe vegetation. Ukrainian Botanical Journal 71 (2): 148-160 [in Ukrainian].

Vynokurov, D. S. 2014b: Syntaxonomy of xerothermic vegetation of the Ingul river valley (Class Festuco-Brometea). Part 2. Meadow, shrub and true steppe vegetation. Ukrainian Botanical Journal 71 (5): 537-548 [in Ukrainian].

Vynokurov, D. 2016: Classification of Pontic-Caspian true steppe vegetation: preliminary overview. In: Agrillo, E., Attorre, F., Spada, F. \& Casella, L. (eds.), 25 ${ }^{\text {th }}$ Meeting of European Vegetation Survey, 6-9 April 2016. Book of Abstracts. Lectures, Roma, p. 74.

Weber, H. E., Moravec, J. \& Theurillat J.-P. 2000: International Code of Phytosociological Nomenclature. 3rd edition. Journal of Vegetation Science 11: 739-768.

Westhoff, V. \& van der Maarel, E. 1973: The Braun-Blanquet approach. In: Whittaker, R.H. (ed.): Handbook of vegetation science, part 5, Classification and ordination of communities. Junk, The Hague: 617-726. 
Table 1: List of broadly-defined taxa used in the numerical analysis.

Tabela 1: Seznam široko opredeljenih taksonov, uporabljenih v numerični analizi.

Achillea millefolium Ajuga chamaepitys Allium flavum Allium paniculatum Allium scorodoprasum Alyssum calycinum Alyssum desertorum Anthemis tinctoria Anthyllis vulneraria Arenaria serpyllifolia Artemisia campestris Asparagus officinalis Asperula supina Aster amellus

Brassica elongata Bromopsis pannonica Campanula sibirica Campanula glomerata Caragana frutex

Carduus hamulosus

Carlina vulgaris

Centaurea scabiosa

Centaurea stoebe

Cerastium pumilum

Cerastium fontanum

Cerastium semidecandrum

Dorycnium pentaphyllum

Elytrigia intermedia

Eremogone saxatilis

Euphorbia nicaeensis

Euphrasia stricta

Festuca valesiaca

Galium aparine

Galium mollugo

Galium verum

Gypsophila altissima

Gypsophila fastigiata

Hylotelephium maximum

Isatis tinctoria

Jurinea mollis

Jurinea stoechadifolia

Jurinea longifolia

Knautia arvensis

Koeleria cristata

Lathyrus pannonicus

Leontodon crispus

Limonium tomentellum

Linaria biebersteinii
A. collina, A. euxina, A. millefolium, A. pannonica, A. setacea, A. stepposa, A. submillefolium

A. chamaepitys, A. chia, A. glabra

A. flavum, A. paczoskianum, A. pseudopulchellum

A. paniculatum, A. podolicum

A. rotundum, A. scorodoprasum, A. waldsteinii

A. calycinum, A. alyssoides

A. desertorum, A. turkestanicum

A. tinctoria, A. tinctoria subsp. subtinctoria

A. vulneraria, A. macrocephala

A. serpyllifolia, A. leptoclados, A. uralensis, A. zozii

A. campestris, A. marschalliana

A. officinalis, A. polyphyllus

A. cimmerica, A. praepilosa, A. supina

A. amellus, A. bessarabicus

B. elongata, Erucastrum armoracioides

B. pannonica, B. pannonica subsp. monoclada

C. praealta, C. sibirica, C. taurica

C. glomerata, C. farinose

C. frutex, C. mollis

C. hamulosus, C. pseudocollinus, C. tauricus

C. biebersteinii, C. intermedia, C. vulgaris

C. adpressa, C. apiculata, C. scabiosa, C. scabiosa subsp. spinulosa

C. biebersteinii, C. pseudomaculosa, C. stoebe, C. stoebe subsp. australis

C. crassiusculum, C. kioviense, C. pumilum Curtis, C. pumilum subsp. glutinosum, C. ucrainicum

C. holosteoides, C. fontanum subsp. vulgare

C. heterotrichum, C. semidecandrum

D. pentaphyllum, D. herbaceum

E. intermedia, E. trichophora

E. micradenia, E. saxatilis

E. glareosa, E. pseudoglareosa, E. stepposa

E. pectinata, E. stricta

F. pseudodalmatica, F. pseudovina, F. rupicola, F. valesiaca

G. aparine, G. spurium, G. vailantii

G. album, G. mollugo

G. ruthenicum, $G$. verum

G. altissima, G. oligosperma, G. thyraica

G. collina, G. dichotoma, G. fastigiata

H. maximum, H. polonicum, H. stepposum

I. tinctoria, I. praecox

J. arachnoidea, J. calcarea, J. mollis, J. transylvanica, J. mollissima

J. stoechadifolia, J. brachycephala

J. longifolia, J. paczoskiana

K. arvensis, K. kitaibelii

K. cristata, K. macrantha

L. lacteus, L. pannonicus

L. biscutellifolius, L. crispus

L. hypanicum, L. alutaceum, L. tomentellum

L. biebersteinii, L. maeotica 
Linum flavum

Linum perenne

Lotus corniculatus

Minuartia setacea

Nepeta ucranica

Nonea pulla

Onobrychis viciifolia

Ononis arvensis

Silene otites

Phlomis tuberosa

Pimpinella tragium

Pimpinella saxifraga

Plantago lanceolata

Plantago media

Potentilla cinerea

Potentilla argentea

Potentilla recta

Poterium sanguisorba

Prunus spinosa

Pulsatilla pratensis

Ranunculus illyricus

Rhinanthus serotinus

Rosa spinosissima

Salvia nemorosa

Salvia pratensis

Scutellaria supina

Sedum sexangulare

Serratula radiata

Seseli tortuosum

Seseli libanotis

Sideritis montana

Teucrium montanum

Thalictrum simplex

Thymus calcareus

Thymus serpyllum

Thymus pulegioides

Tragopogon dubius

Valeriana officinalis

Verbascum chaixii

Veronica austriaca

Veronica spicata
L. czernjajevii, L. ucranicum, L. flavum, L. linearifolium

L. austriacum, L. perenne

L. arvensis, L. corniculatus, L. ucrainicus

M. leiosperma, M. setacea, M. thyraica

N. parviflora, N. ucranica

N. pulla, N. rossica

O. arenaria, O. gracilis, O. miniata, O. tanaitica, O. viciifolia

O. spinosa, O. arvensis

Otites artemisetorum, O. borysthenicus, O. chersonensis, O. densiflorus, O. dolichocarpus,

O. eugeniae, O. hellmannii, O. orae-syvaschicae, O. wolgensis, Silene baschkirorum, Silene exaltata

P. hybrida, P. tuberosa, P. scythica

P. lithophila, P. tragium, P. titanophila

P. saxifraga, P. saxifraga subsp. nigra

P. lanceolata, P. lanceolata subsp. lanuginosa

P. media, P. urvillei

P. cinerea, P. incana

P. argentea, P. inclinata, P. neglecta

P. astracanica, P. mollicrinis, P. recta, P. obscura, P. pedata, P. pilosa, P. semilaciniosa, P. taurica

P. polygamum, P. sanguisorba

P. spinosa, P. stepposa

P. pratensis, P. bohemica

R. illyricus, R. scythicus

R. aestivalis, R. serotinus, R. vernalis

R. pimpinellifolia, R. spinosissima

S. nemorosa, S. tesquicola

S. pratensis, S. transsylvanica, S. stepposa

S. creticola, S. verna

S. borissovae, S. sexangulare

S. bracteifolia, S. radiata

S. campestre, S. tortuosum

S. libanotis, S. libanotis subsp. intermedium

S. montana, S. comosa

T. montanum, T. pannonicum

T. simplex, T. simplex subsp. galioides

T. calcareus, T. cretaceous

T. glabrescens T. serpyllum

T. marschallianus, T. pannonicus, T. pulegioides

T. dubius, T. major

V. officinalis, V. stolonifera

V. austriacum, V. marschallianum

V. austriaca, V. jacquinii, V. sclerophylla

V. barrelieri, V. maeotica, V. orchidea, V. spicata 
Table 2: Shortened synoptic table of steppe communities of the study area with percentage frequencies and phi fidelity indices (in the superscript). Species with frequencies $>20 \%$ at least in one cluster or with fidelity $>20 \%$ in at least one cluster are included.

Tabela 2: Skrajšana sinoptična tabela stepskih združb v preučevanem območju s frekvencami v odstotkih in fi indeksi (nadpisano). Vključene so vrste s frekvenco > 20\% vsaj v enem klastru ali navezanostjo > 20\% vsaj v enem klastru.

\begin{tabular}{|lrrrrrrrrrrrr}
\hline Codes of syntaxa & $\mathrm{A} 1$ & $\mathrm{~B} 1$ & $\mathrm{~B} 2$ & $\mathrm{~B} 3$ & $\mathrm{C} 1 \mathrm{a}$ & $\mathrm{C} 1 \mathrm{~b}$ & $\mathrm{C} 2 \mathrm{a}$ & $\mathrm{C} 2 \mathrm{~b}$ & $\mathrm{C} 3$ & $\mathrm{C} 4$ & $\mathrm{H} 1$ \\
Average total cover of vegetation (\%) & 80 & 75 & 75 & 70 & 70 & 55 & 70 & 80 & 70 & 75 & 80 \\
Number of relevés & 32 & 39 & 35 & 49 & 44 & 26 & 41 & 20 & 51 & 20 & 17 \\
\hline
\end{tabular}

Diagnostic species for the association Goniolimono taurici-Poetum angustifoliae:

\begin{tabular}{|c|c|c|c|c|c|c|c|c|c|c|}
\hline Elytrigia repens & $94^{30.1}$ & 62 & 57 & 41 & 30 & 19 & 32 & 20 & 65 & 40 \\
\hline Thalictrum minus & $41^{28.9}$ & & 3 & . & 11 & 12 & 32 & 25 & 2 & . \\
\hline Euphorbia virgata & $19^{25.3}$ & & . & . & & . & . & . & 12 & 10 \\
\hline
\end{tabular}

Diagnostic species for the association Ferulo orientalis-Agropyretum pectinati:

Elytrigia elongata

Bupleurum marschallianum

Poa angustifolia

Diagnostic species for the association Agropyro pectinati-Artemisietum tauricae:

$\begin{array}{lrrrrr}\text { Cardaria draba } & 19 & 31 & 46^{30} & 20 & 11 \\ \text { Ferula euxina } & \cdot & 12 & 20^{29.4} & 4 & . \\ \text { Consolida paniculata } & 19 & 31 & 49^{28.5} & 6 & 5 \\ \text { Artemisia taurica } & 12 & 19 & 49^{27.5} & 16 & 30\end{array}$

Diagnostic species for the association Cerastio syvashici-Poetum bulbosae

Leymus ramosus

Prangos odontalgica

Ornithogalum kochii

Lepidium perfoliatum

Taraxacum erythrospermum

Trifolium arvense

Lamium amplexicaule

Cerastium syvaschicum

Caroxylon laricinum

Vicia tetrasperma

Viola kitaibeliana

Erodium ciconium

Galium tenuissimum

Linaria macroura

$\begin{array}{rllllllllll}3 & 44^{41.9} & 23^{17.4} & . & 7 & 6 & 5 & . & . & . & . \\ . & 25^{35.5} & 11 & . & 5 & . & . & . & . & . & . \\ 28 & 44^{27.9} & 31^{16.5} & . & 2 & . & . & . & 6 & . & 38\end{array}$

1

.

. $18 \quad 20 \quad 25$

$\begin{array}{lllll}19 & 5 & 5 & 6 & 20\end{array}$

Diagnostic species for the subassociation Stipo brauneri-Bromopsidetum cappadocicae typicum:

\begin{tabular}{|c|c|c|c|c|c|c|c|c|c|c|c|}
\hline Stipa brauneri & 3 & . & . & . & $32^{28}$ & $50^{49.4}$ & . & . & 2 & . & . \\
\hline Scorzonera mollis & 9 & . & . & 4 & $50^{25.8}$ & $56^{30.9}$ & 14 & 15 & 12 & 30 & 12 \\
\hline Bromopsis cappadocica & . & 6 & 6 & . & $25^{14.3}$ & $69^{58.6}$ & 5 & . & . & 10 & . \\
\hline Teucrium chamaedrys & 12 & 12 & 6 & . & $34^{32.6}$ & 6 & 9 & . & . & . & . \\
\hline Orchis picta & 3 & . & . & . & $23^{31.4}$ & 6 & 5 & 5 & . & . & . \\
\hline Ornithogalum flavescens & 6 & . & . & 2 & $23^{31.3}$ & 6 & 5 & . & . & . & . \\
\hline Dactylis glomerata & 28 & 6 & 20 & 2 & $36^{26.4}$ & 12 & 5 & 5 & 2 & . & . \\
\hline Plantago lanceolata & 6 & 44 & 37 & . & $45^{25.3}$ & . & 14 & . & 14 & . & 12 \\
\hline
\end{tabular}

Diagnostic species for the subassociation Stipo brauneri-Bromopsidetum cappadocicae jurineetosum stoechadifoliae: Jurinea stoechadifolia

Dianthus capitatus

Artemisia lerchiana

$588^{89.3}$

2

Alyssum tortuosum

Astragalus pubiflorus

$\begin{array}{ccccccc}\cdot & . & . & . & 5 & 88^{89.3} & \\ . & \cdot & . & . & 2 & 56^{68.7} & 5 \\ 3 & . & . & . & . & 38^{51.9} & 5 \\ . & \cdot & . & . & . & 19^{41.6} & \\ . & . & . & . & 2 & 19^{38.9}\end{array}$




\begin{tabular}{|c|c|c|c|c|c|c|c|c|c|c|c|}
\hline Codes of syntaxa & A1 & B1 & B2 & B3 & $\mathrm{C} 1 \mathrm{a}$ & $\mathrm{C} 1 \mathrm{~b}$ & $\mathrm{C} 2 \mathrm{a}$ & $\mathrm{C} 2 \mathrm{~b}$ & C3 & C4 & $\mathrm{H} 1$ \\
\hline Average total cover of vegetation (\%) & 80 & 75 & 75 & 70 & 70 & 55 & 70 & 80 & 70 & 75 & 80 \\
\hline Number of relevés & 32 & 39 & 35 & 49 & 44 & 26 & 41 & 20 & 51 & 20 & 17 \\
\hline Veronica verna & $\cdot$ & . & 6 & . & 2 & $25^{34.9}$ & 9 & . & . & . & . \\
\hline Koeleria cristata & 19 & 6 & 11 & 8 & $55^{14.6}$ & $75^{28.4}$ & 36 & 25 & 41 & 10 & 75 \\
\hline \multicolumn{12}{|c|}{ Diagnostic species for the subassociation Ephedro distachyae-Stipetum capillatae typicum: } \\
\hline Stipa capillata & 3 & 12 & 6 & 51 & 11 & 25 & $100^{38.8}$ & 65 & 18 & 60 & 88 \\
\hline Linaria genistifolia & 6 & 6 & 6 & . & . & . & $36^{29.1}$ & 25 & 12 & . & 12 \\
\hline
\end{tabular}

Diagnostic species for the subassociation Ephedro distachyae-Stipetum capillatae helichrysetosum arenarii:

Helichrysum arenarium

\begin{tabular}{|c|c|c|c|c|c|c|c|c|c|}
\hline . & . & . & & 6 & 14 & $50^{52.1}$ & . & 10 & \\
\hline 6 & 3 & . & 2 & 6 & . & $50^{50.7}$ & . & . & 12 \\
\hline 6 & 3 & . & . & . & . & $40^{45.5}$ & 4 & & 12 \\
\hline . & 3 & 8 & 2 & . & 9 & $45^{41.3}$ & 4 & 10 & 12 \\
\hline . & . & . & . & . & . & $20^{38.6}$ & 4 & . & \\
\hline . & . & . & 7 & 6 & 5 & $30^{37.9}$ & 4 & . & \\
\hline . & . & 2 & . & . & 9 & $40^{37.3}$ & 2 & 10 & 25 \\
\hline . & . & . & . & . & · & $15^{37.2}$ & . & . & \\
\hline . & . & . & . & . & . & $15^{34.5}$ & 2 & . & \\
\hline . & . & . & . & . & . & $15^{34.5}$ & 2 & . & \\
\hline . & . & . & . & . & 14 & $25^{32.1}$ & 6 & . & \\
\hline . & . & . & 16 & 25 & 14 & $35^{30.6}$ & 2 & . & \\
\hline 6. & 20 & 45 & 2 & . & 23 & $75^{29.5}$ & $57^{17.2}$ & 60 & 38 \\
\hline 19 & 23 & 41 & 14 & 38 & 23 & $75^{26.7}$ & 49 & 30 & 50 \\
\hline
\end{tabular}

Echinops ruthenicus

Achillea leptophylla

Limonium sareptanum

Herniaria besseri

Tragopogon dasyrhynchus

Jurinea multiflora

Astragalus varius

Polygonum aviculare

Polycnemum arvense

Asparagus officinalis

Thymus $x$ dimorphus

Artemisia austriaca

1923

Kochia prostrata

aceto millefolii-Salvietum nemorosae:

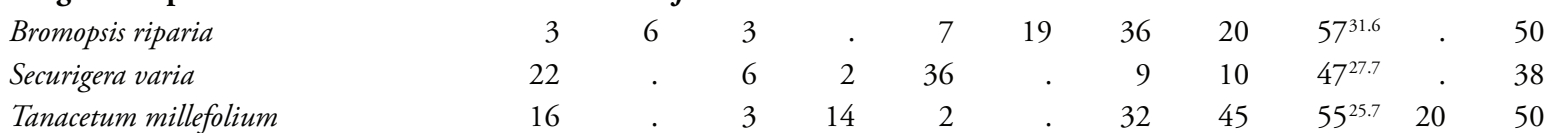

Diagnostic species for the association Stipo ucrainicae-Agropyretum pectinati:

Stipa ucrainica

Serratula erucifolia

Diagnostic species for the association Stipo lessingianae-Salvietum nutantis

Stipa lessingiana

Stachys recta

Salvia nutans

Asperula cynanchica

Medicago falcata

Diagnostic species for the alliance Artemisio tauricae-Festucion valesiacae

Artemisia santonicum

Limonium meyeri

$\begin{array}{rcccc}12 & 69^{51.9} & 46^{30.4} & 6 & . \\ 6 & 62^{42.9} & 57^{38.1} & 8 & 2 \\ . & . & . & 14^{22.4} & .\end{array}$

Limonium tschurjukiense

Diagnostic species for the alliance Tanaceto millefolii-Galatellion villosae:

Ephedra distachya

Salvia nemorosa

Tulipa gesneriana

Sideritis montana

Jurinea mollis

Silene otites aggr.

Centaurea diffusa

Pleconax subconica

Myosotis micrantha

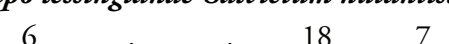

3

3

$$
\left(\frac{10}{10}\right.
$$$$
\text { (6) }
$$$$
\text { . } 2
$$$$
2
$$$$
1
$$$$
25
$$

$$
\begin{array}{r}
12 \\
\cdot \\
\cdot \\
\cdot \\
12 \\
38
\end{array}
$$$$
\begin{array}{rrrrr}
5 & 15 & 4 & 80^{62.9} & 12 \\
9 & 5 & 14 & 70^{48.4} & 25
\end{array}
$$$$
\begin{array}{crrrr}
9 & 35 & 16 & \cdot & 88^{61.1} \\
18 & \cdot & 6 & \cdot & 50^{53.6} \\
32^{18.8} & 20 & 8 & 10 & 62^{48.3} \\
. & 10 & 12 & . & 50^{45.4} \\
27 & 45 & 59^{18.4} & 10 & 88^{37.9}
\end{array}
$$ 


$\begin{array}{lrrrrrrrrrrr}\text { Codes of syntaxa } & \mathrm{A} 1 & \mathrm{~B} 1 & \mathrm{~B} 2 & \mathrm{~B} 3 & \mathrm{C} 1 \mathrm{a} & \mathrm{C} 1 \mathrm{~b} & \mathrm{C} 2 \mathrm{a} & \mathrm{C} 2 \mathrm{~b} & \mathrm{C} 3 & \mathrm{C} 4 & \mathrm{H} 1 \\ \text { Average total cover of vegetation (\%) } & 80 & 75 & 75 & 70 & 70 & 55 & 70 & 80 & 70 & 75 & 80 \\ \text { Number of relevés } & 32 & 39 & 35 & 49 & 44 & 26 & 41 & 20 & 51 & 20 & 17 \\ \text { Euphorbia seguieriana } & 25 & 12 & 14 & 20 & 59^{14.6} & 31 & 41 & 65 & 31 & 30 & 75 \\ \text { Dianthus elongatus } & 3 & 6 & 3 & . & 32^{18.1} & . & 23 & . & 25 & 10 & 38 \\ \text { Muscari neglectum } & 3 & . & . & . & 11^{23.4} & . & 5 & . & . & .\end{array}$

Diagnostic species for the order Galatello villosae-Stipetalia lessingianae:

\begin{tabular}{|c|c|c|c|c|c|c|c|c|c|c|c|}
\hline & & & & & & & & & & & \\
\hline Agropyron pectinatum & 34 & 19 & 49 & 59 & 32 & 38 & 64 & 85 & $75^{15}$ & 80 & 25 \\
\hline Galatella villosa & 3 & 6 & 6 & 29 & $80^{23.4}$ & 75 & 41 & 40 & 37 & 80 & 75 \\
\hline Phlomis pungens & 31 & 6 & 9 & 43 & 30 & 38 & 23 & 20 & 37 & 30 & 50 \\
\hline Poa bulbosa & 31 & 31 & 29 & 57 & 34 & 19 & 50 & 30 & 45 & 30 & . \\
\hline Alyssum desertorum & 6 & . & . & 20 & 14 & 19 & 9 & 10 & 20 & 10 & \\
\hline Carduus uncinatus & 12 & 19 & 11 & $57^{23.4}$ & 41 & 25 & 36 & . & 33 & 40 & . \\
\hline Cruciata pedemontana & . & . & 3 & $14^{15}$ & 2 & . & . & . & . & 30 & \\
\hline \multicolumn{12}{|c|}{ Diagnostic species for the class Festuco-Brometea: } \\
\hline Galium verum & 12 & . & 3 & . & $34^{14}$ & 44 & 14 & 30 & 6 & 10 & 38 \\
\hline Teucrium polium & 3 & 6 & 9 & . & 18 & 44 & $45^{21.5}$ & 25 & 10 & 10 & 38 \\
\hline Filipendula vulgaris & . & . & . & . & $11^{24.6}$ & 6 & . & . & . & . & . \\
\hline Eryngium campestre & 25 & 50 & 40 & 16 & 57 & 62 & $73^{21.5}$ & 45 & 31 & 10 & 25 \\
\hline Festuca valesiaca & 66 & 81 & 57 & 82 & 86 & 81 & 82 & 95 & $96^{12}$ & 80 & 88 \\
\hline Botriochloa ischaemum & 3 & . & . & . & $16^{23.2}$ & 6 & 9 & . & . & . & . \\
\hline Achillea millefolium & 38 & 31 & 34 & 12 & 23 & 19 & 5 & 10 & 8 & 20 & 38 \\
\hline Falcaria vulgaris & 44 & 19 & 34 & 47 & 27 & 12 & 36 & 40 & 51 & 40 & 62 \\
\hline Linum perenne & 12 & . & 6 & 6 & $45^{23.6}$ & 38 & 5 & 5 & 25 & 10 & 38 \\
\hline Cerastium glomeratum & . & . & . & . & $11^{22.9}$ & 6 & . & . & 2 & . & . \\
\hline Seseli tortuosum & 12 & 25 & 14 & 6 & 20 & 6 & 32 & 25 & 12 & 20 & 38 \\
\hline Crepis tectorum & 22 & 12 & 9 & $33^{15.4}$ & 7 & . & 5 & 10 & 8 & 50 & 12 \\
\hline Salvia aethiopis & 9 & . & 17 & $31^{24.1}$ & 7 & . & 9 & 15 & 10 & . & . \\
\hline Potentilla recta & 19 & . & 6 & 12 & 34 & 38 & 55 & $30^{21.1}$ & 20 & 20 & 62 \\
\hline Senecio vernalis & 34 & 6 & 6 & $35^{20.9}$ & . & . & 5 & 5 & 14 & 10 & 25 \\
\hline \multicolumn{12}{|l|}{ Other species: } \\
\hline Galium humifusum & 22 & 38 & 37 & 8 & 2 & . & . & 10 & 22 & 10 & \\
\hline Artemisia absinthium & $16^{24.5}$ & . & 3 & . & . & . & . & . & . & . & 12 \\
\hline Galium aparine & 9 & 12 & 11 & $20^{19.8}$ & . & . & . & . & . & 10 & . \\
\hline Atriplex tatarica & 6 & . & 9 & $20^{21.7}$ & . & . & . & 10 & 2 & 10 & . \\
\hline
\end{tabular}


Table 3: Floristic table of the new syntaxa of the alliance Artemisio tauricae-Festucion valesiacae: associations Agropyro pectinatiArtemisietum tauricae (rel. 1-10), Cerastio syvashici-Poetum bulbosae (rel. 11-20).

Tabela 3: Floristična tabela novih sintaksonov zveze Artemisio tauricae-Festucion valesiacae: asociaciji Agropyro pectinati-Artemisietum tauricae (popisi 1-10), Cerastio syvashici-Poetum bulbosae (popisi 11-20).

\begin{tabular}{lccccccccccccccccccccc}
\hline Relevé № & 1 & 2 & 3 & 4 & 5 & 6 & 7 & 8 & 9 & 10 & 11 & 12 & 13 & 14 & 15 & 16 & 17 & 18 & 19 & 20 \\
Slope $\left(^{\circ}\right)$ & 5 & 1 & 1 & 0 & 1 & 5 & 5 & 5 & 3 & 15 & 1 & 5 & 0 & 10 & 1 & 1 & 3 & 10 & 1 & 2 \\
Aspect $\left(^{\circ}\right)$ & 160 & 20 & 0 & 90 & 90 & 320 & 90 & 50 & 340 & 100 & 200 & 170 & 350 & 350 & 180 & 15 & 180 & 10 & 90 & 270 \\
Cover $(\%)$ & 60 & 90 & 70 & 90 & 60 & 70 & 70 & 70 & 60 & 70 & 65 & 85 & 70 & 70 & 90 & 80 & 70 & 60 & 90 & 70 \\
\hline
\end{tabular}

Diagnostic species for the association Agropyro pectinati-Artemisietum tauricae

Artemisia taurica

Anisantha tectorum

Consolida paniculata

\begin{tabular}{|llllllllll|}
\hline 3 & 2 & 3 & 3 & 2 & 3 & 4 & 4 & 3 & 3 \\
1 & $\cdot$ & 1 & $\cdot$ & $\cdot$ & $\cdot$ & 1 & $\cdot$ & 1 & 1 \\
1 & 1 & + &. &. & + & 1 &. & + & + \\
\hline
\end{tabular}

Diagnostic species for the association Cerastio syvashici-Poetum bulbosae

Ornithogalum kochii

Cerastium syvaschicum

Myosotis micrantha

Stipa capillata

Taraxacum erythrospermum

Diagnostic species for the alliance Artemisio tauricae-Festucion valesiacae

Limonium meyeri

Agropyron pectinatum

Atriplex tatarica

Tulipa gesneriana

Galium tenuissimum

Marrubium peregrinum

Cardaria draba

Peganum harmala

Trifolium retusum

Diagnostic species for the class Festuco-Brometea

Artemisia austriaca

Stipa ucrainica

Serratula erucifolia

Tragopogon major

Senecio vernalis

Salvia nemorosa aggr.

Potentilla obscura

Bromus squarrosus

Crepis tectorum

Festuca valesiaca

Centaurea diffusa

Galatella villosa

Eryngium campestre

Kochia prostrate

Poa bulbosa

Phlomis pungens

Carduus uncinatus

Falcaria vulgaris

Lactuca serriola

Verbascum densiflorum

Linum austriacum 


\begin{tabular}{lccccccccccccccccccccc}
\hline Relevé № & 1 & 2 & 3 & 4 & 5 & 6 & 7 & 8 & 9 & 10 & 11 & 12 & 13 & 14 & 15 & 16 & 17 & 18 & 19 & 20 \\
Slope $\left(^{\circ}\right)$ & 5 & 1 & 1 & 0 & 1 & 5 & 5 & 5 & 3 & 15 & 1 & 5 & 0 & 10 & 1 & 1 & 3 & 10 & 1 & 2 \\
Aspect $\left({ }^{\circ}\right)$ & 160 & 20 & 0 & 90 & 90 & 320 & 90 & 50 & 340 & 100 & 200 & 170 & 350 & 350 & 180 & 15 & 180 & 10 & 90 & 270 \\
Cover $(\%)$ & 60 & 90 & 70 & 90 & 60 & 70 & 70 & 70 & 60 & 70 & 65 & 85 & 70 & 70 & 90 & 80 & 70 & 60 & 90 & 70 \\
\hline
\end{tabular}

\section{Other species}

Elytrigia repens

Vicia cracca

Galium aparine

Lamium amplexicaule

Viola kitaibeliana

Salvia aethiopis

Anthemis ruthenica

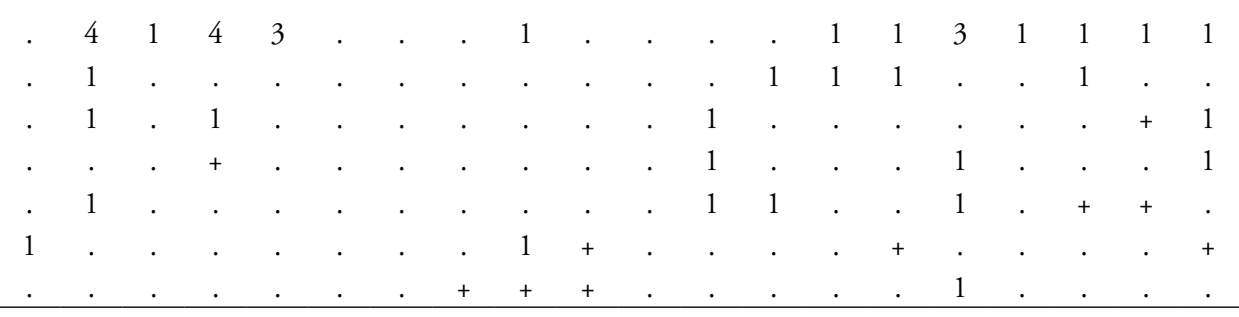

Species with small frequency: Achillea setacea $(3: 1 ; 8: 1 ; 10: 1)$, Acroptilon repens $(3: 2 ; 18: 1)$, Adonis flammea $(17:+)$, Alcea rugosa (8: 1), Allium guttatum (18:+), A. rotundum (2: 1; 7: 1), Alyssum desertorum (11:1; 12: +; 18: 1), A. hirsutum (7: +; 17: 1), Anthemis cotula (3: 1), Arenaria uralensis (10: +), Artemisia absinthium (8: 1), A. santonicum (20: 1), Asparagus polyphyllus (14: 1), Astragalus asper (14: 1), A. corniculatus (12: 1), A. reduncus (12: 1), A. ucrainicus (11: 1), Bellevalia sarmatica (11: +), Bromus hordeaceus (6: +; 10: 3), Buglossoides arvensis (13:+), Camphorosma monspeliaca (20: 1), Capsella bursa-pastoris (3: 1; 7:+), Carduus acanthoides (9: 1), C. tauricus (8: +), Caroxylon laricinum (2: 1), Centaurea adpressa (14: 1), C. salonitana (7: +), Cerastium perfoliatum (4: 1), Chondrilla juncea $(7:+)$, Cirsium arvense $(3: 1 ; 8: 1)$, Clinopodium vulgare $(8:+)$, Conium maculatum (2: 1), Convolvulus arvensis (3: 1; 5: +; 10: 1), Conyza canadensis (3:+), Cruciata pedemontana (14: 1; 16:1), Dactylis glomerata (8: 3), Dasypyrum villosum (6: 2), Dianthus elongatus $(7:+)$, Dichodon viscidum $(3: 1 ; 4: 1 ; 20: 1)$, Diplotaxis tenuifolia $(9: 1)$, Elisanthe viscosa $(13: 1 ; 19:+)$, Ephedra distachya (7: 2; 14: 1; 17: 1), Erodium cyconium $(18:+)$, Euphorbia leptocaula $(18:+)$, E. seguieriana $(15: 1 ; 16: 1 ; 20: 1)$, Ferula caspica (12: +), Galatella dracunculoides (1: 1; 2: 1; 8: 1), Galium humifusum $(5: 1 ; 10: 1 ; 17: 1)$, G. ruthenicum (7: 1; 8: 1), Geranium pusillum (20: 1), Goniolimon tataricum (1: 1), Heliotropium suaveolens (6: +), Hyoscyamus niger (2: 1), Iris pumila (11: 1; 12: 1), Jurinea multiflora $(7:+)$, Koeleria cristata $(1: 1 ; 11: 1 ; 16: 1)$, Kohlrauschia prolifera $(6:+; 9:+)$, Lactuca tatarica (13: 1), Leopoldia comosa (5: +), Lepidium perfoliatum (12: 1), Limonium sareptanum (5: 1; 7: +;17:1), L. tschurjukiense (19: 1), Linaria genistifolia (1: 1), L. macroura (16: +), Malva mauritiana (6: +), M. pusilla (13: 1), Medicago falcata (4: 1; 7: 1; 14: 1), M. lupulina (13: 1; 15: 1; 16: 1), M. sativa (7: +), Meniocus linifolius (17: 1), Nigella arvensis (5:+), Ornithogalum ponticum (18:+), Otites artemisetorum (7: +; 9:+), O. densiflorus (7: +; 8:+), Papaver dubium (2: 1; 5: +; 14:+), P. hybridum (9:+), P. rhoeas (9: +), Pastinaca clausii (15: 1), Phelipanche lanuginosa $(1:+)$, Plantago lanceolata subsp. lanuginosa (1: 1; 5: 1), Pleconax subconica (14: 1; 18: +), Poa angustifolia (5: 1; 10: 1), Potentilla argentea (10: 1), P. semilaciniosa (4: 1), Prangos odontalgica (2: 1), Pterotheca sancta (20: 1), Ranunculus oxyspermus (12: +; 16: 1), R. scythicus (20: 1), Scleranthus verticillatus (16: 1), Scolymus hispanicus (5: +; 6: +), Securigera varia (1: 1; 14: 1), Senecio jacobaea (3: +), Seseli tortuosum (1: +; 5: +; 20: 1), Sisymbrium loeselii (18: 1), Stipa lessingiana (12: 1), Tanacetum millefolium (11: 1; 12: 1; 19: 1), Thlaspi perfoliatum (10:+), Thymelaea passerina (9: +), Trifolium arvense (13: 1; 18: 1; 20:1), T. dubium (18: +), Trinia hispida $(16:+)$, Valeriana tuberosa $(4:+; 13:+)$, Valerianella costata $(4: 1)$, Verbascum blattaria $(1:+; 16:+)$, V. phoeniceum $(9:+)$, Veronica teucrium (4: 1), V. triphyllos $(10:+; 11: 1 ; 20: 1)$, Vicia angustifolia $(4: 1 ; 6: 1)$, V. lathyroides $(4: 1 ; 14: 1 ; 17: 1)$, V. tetrasperma (14: 1).

\section{Localities:}

1 - $46^{\circ} 21^{\prime} 04.39^{\prime \prime} \mathrm{N}, 35^{\circ} 05^{\prime} 04.35^{\prime \prime} \mathrm{E}(19.07 .2005) ; 2-46^{\circ} 08^{\prime} 35.17^{\prime \prime} \mathrm{N}, 34^{\circ} 15^{\prime} 57.90^{\prime \prime} \mathrm{E}(04.07 .2006)$; $3-46^{\circ} 10^{\prime} 56.70^{\prime \prime} \mathrm{N}, 34^{\circ} 14^{\prime} 31.51^{\prime \prime} \mathrm{E}$ (16.06. 2005); 4- 46 08' 14.57” N, $34^{\circ} 16^{\prime} 05.60^{\prime \prime} \mathrm{E}(04.07 .2006)$; $5-45^{\circ} 21^{\prime} 25.33^{\prime \prime} \mathrm{N}, 35^{\circ} 05^{\prime} 23.64^{\prime \prime} \mathrm{E}$ (12.08. 2011); 6- $45^{\circ} 28^{\prime} 51.23^{\prime \prime} \mathrm{N}, 36^{\circ} 20^{\prime} 26.61^{\prime \prime} \mathrm{E}(09.09 .2011)$;

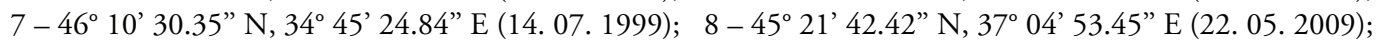
$9-45^{\circ} 17^{\prime} 12.84^{\prime \prime} \mathrm{N}, 35^{\circ} 30^{\prime} 23.13^{\prime \prime} \mathrm{E}$ (08. 06. 2009); 10 - $45^{\circ} 45^{\prime} 08.57^{\prime \prime} \mathrm{N}, 34^{\circ} 42^{\prime} 38.55^{\prime \prime} \mathrm{E}$ (31. 05. 2012);

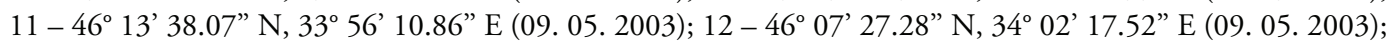
$13-46^{\circ} 07^{\prime} 16.34^{\prime \prime} \mathrm{N}, 34^{\circ} 27^{\prime} 02.99^{\prime \prime} \mathrm{E}$ (22.04. 2011); $14-46^{\circ} 04^{\prime} 57.31^{\prime \prime} \mathrm{N}, 34^{\circ} 14^{\prime} 36.70^{\prime \prime} \mathrm{E}(12.05 .2011)$; $15-46^{\circ} 07^{\prime} 36.32^{\prime \prime} \mathrm{N}, 34^{\circ} 02^{\prime} 18.03^{\prime \prime} \mathrm{E}$ (12.05. 2011); $16-46^{\circ} 05^{\prime} 52.01^{\prime \prime} \mathrm{N}, 34^{\circ} 01^{\prime} 25.51^{\prime \prime} \mathrm{E}$ (12. 05. 2011); $17-46^{\circ} 23^{\prime} 54.82^{\prime \prime} \mathrm{N}, 36^{\circ} 06^{\prime} 34.61^{\prime \prime} \mathrm{E}(13.05 .2011)$; $18-46^{\circ} 05^{\prime} 16.21^{\prime \prime} \mathrm{N}, 34^{\circ} 18^{\prime} 21.84^{\prime \prime} \mathrm{E}(26.05 .2010)$; $19-46^{\circ} 09^{\prime} 49.81^{\prime \prime} \mathrm{N}, 33^{\circ} 48^{\prime} 43.18^{\prime \prime} \mathrm{E}(23.09 .2011) ; 20-46^{\circ} 35^{\prime} 52.25^{\prime}$ N, $35^{\circ} 22^{\prime} 01.83^{\prime \prime} \mathrm{E}(27.04 .2013)$. 
Table 4: Floristic table of the new syntaxa of the alliance Tanaceto millefolii-Galatellion villosae: associations Stipo brauneri-Bromopsidetum cappadocicae (rel. 1-20), Ephedro distachyae-Stipetum capillatae (rel. 21-40).

\begin{tabular}{lcccccccccccccccccc}
\hline Relevé № & 1 & 2 & 3 & 4 & 5 & 6 & 7 & 8 & 9 & 10 & 11 & 12 & 13 & 14 & 15 & 16 & 17 \\
Slope $\left(^{\circ}\right)$ & 7 & 3 & 1 & 5 & 7 & 7 & 3 & 2 & 5 & 2 & 7 & 7 & 3 & 3 & 10 & 15 & 3 \\
Aspect $\left({ }^{\circ}\right)$ & 50 & 270 & 10 & 320 & 320 & 40 & 30 & 270 & 340 & 0 & 10 & 345 & 345 & 360 & 320 & 300 & 0 \\
Cover $(\%)$ & 70 & 80 & 60 & 60 & 60 & 75 & 80 & 70 & 70 & 60 & 90 & 60 & 70 & 70 & 60 & 60 & 50 \\
\hline
\end{tabular}

Diagnostic species for the subassociation Stipo brauneri-Bromopsidetum cappadocicae typicum

Stipa brauneri

Orchis picta

\begin{tabular}{|llllllllll|}
\hline 1 & 2 & 1 &. &. & 5 & 5 &. &. & 5 \\
. &. & + &. &. &. & + &. & + &. \\
\hline
\end{tabular}

Diagnostic species for the subassociation Stipo brauneri-Bromopsidetum cappadocicae jurineetosum stoechadifoliae Jurinea stoechadifolia

Dianthus capitatus

Bromopsis cappadocica

Cephalaria uralensis

\begin{tabular}{rrrrrrr}
2 & + & 3 & $\cdot$ & $\cdot$ & 1 & 3 \\
$\cdot$ & $\cdot$ & + & $\cdot$ & + & 1 & + \\
1 & 1 & 1 & 3 & $\cdot$ & $\cdot$ & $\cdot$ \\
1 & $\cdot$ & $\cdot$ & 1 & $\cdot$ & 1 & 1 \\
\hline
\end{tabular}

Diagnostic species for the subassociation Ephedro distachyae-Stipetum capillatae typicum

Stipa capillata

Linaria genistifolia

Diagnostic species for the subassociation Ephedro distachyae-Stipetum capillatae helichrysetosum arenarii

Helichrysum arenarium

Echinops ruthenicus

Achillea leptophylla

Tragopogon dasyrhynchus

Astragalus varius

Asparagus polyphyllus

Artemisia austriaca

Diagnostic species for the alliance Tanaceto millefolii-Galatellion villosae

Ephedra distachya

Agropyron pectinatum

Scorzonera mollis

Poa bulbosa

Galatella villosa

Kochia prostrata

Bromus squarrosus

Tanacetum millefolium

Stipa lessingiana

Seseli tortuosum

Limonium platyphyllum

Jurinea arachnoidea

Otites densiflorus

Iris pumila

Potentilla astracanica

Verbascum blattaria

Achillea nobilis

Teucrium polium

Marrubium peregrinum

Dianthus elongatus

Goniolimon tataricum

Chondrilla juncea

Bellevalia sarmatica

Koblrauschia prolifera

Senecio erucifolius

Arenaria uralensis 
Tabela 4: Floristična tabela novih sintaksonov zveze Tanaceto millefolii-Galatellion villosae: asociaciji Stipo brauneri-Bromopsidetum cappadocicae (popisi 1-20), Ephedro distachyae-Stipetum capillatae (popisi 21-40).

\begin{tabular}{ccccccccccccccccccccccc}
18 & 19 & 20 & 21 & 22 & 23 & 24 & 25 & 26 & 27 & 28 & 29 & 30 & 31 & 32 & 33 & 34 & 35 & 36 & 37 & 38 & 39 & 40 \\
3 & 7 & 2 & 3 & 7 & 10 & 7 & 3 & 7 & 5 & 7 & 10 & 5 & 20 & 15 & 25 & 15 & 20 & 5 & 3 & 7 & 5 & 2 \\
220 & 0 & 0 & 100 & 80 & 150 & 180 & 150 & 90 & 340 & 320 & 120 & 100 & 100 & 100 & 100 & 90 & 100 & 90 & 100 & 90 & 90 & 0 \\
50 & 70 & 60 & 80 & 85 & 55 & 70 & 85 & 75 & 60 & 70 & 70 & 80 & 85 & 85 & 85 & 75 & 75 & 90 & 75 & 70 & 60 & 70 \\
\hline
\end{tabular}

$$
2
$$

\begin{tabular}{lll|}
\hline 3 & 3 & 1 \\
$\cdot$ & $\cdot$ & $\cdot$ \\
1 & 1 & $\cdot$ \\
$\cdot$ & $\cdot$ & $\cdot$ \\
\hline
\end{tabular}

\begin{tabular}{|cccccccccc|}
\hline 3 & 3 & 3 & 3 & 1 & 4 & 3 & 4 & 3 & 2 \\
. & + &. & 1 &. &. & 1 &. &. &. \\
\hline
\end{tabular}

\begin{tabular}{|cccccccccc|}
\hline 1 & 1 & 1 & 1 & 1 & 1 & 2 &. &. & 1 \\
1 & + & + & + & + &. & 1 & + &. &. \\
1 & 1 & 1 & 2 & 1 &. &. & 1 &. &. \\
+ & + & + & + & 1 &. &. &. &. &. \\
. & 1 &. & + &. &. &. &. & + &. \\
+ & 1 &. &. &. & + &. &. & + & + \\
. & 1 & 1 & 2 & 1 & 1 & 1 & 1 & 1 &. \\
\hline
\end{tabular}

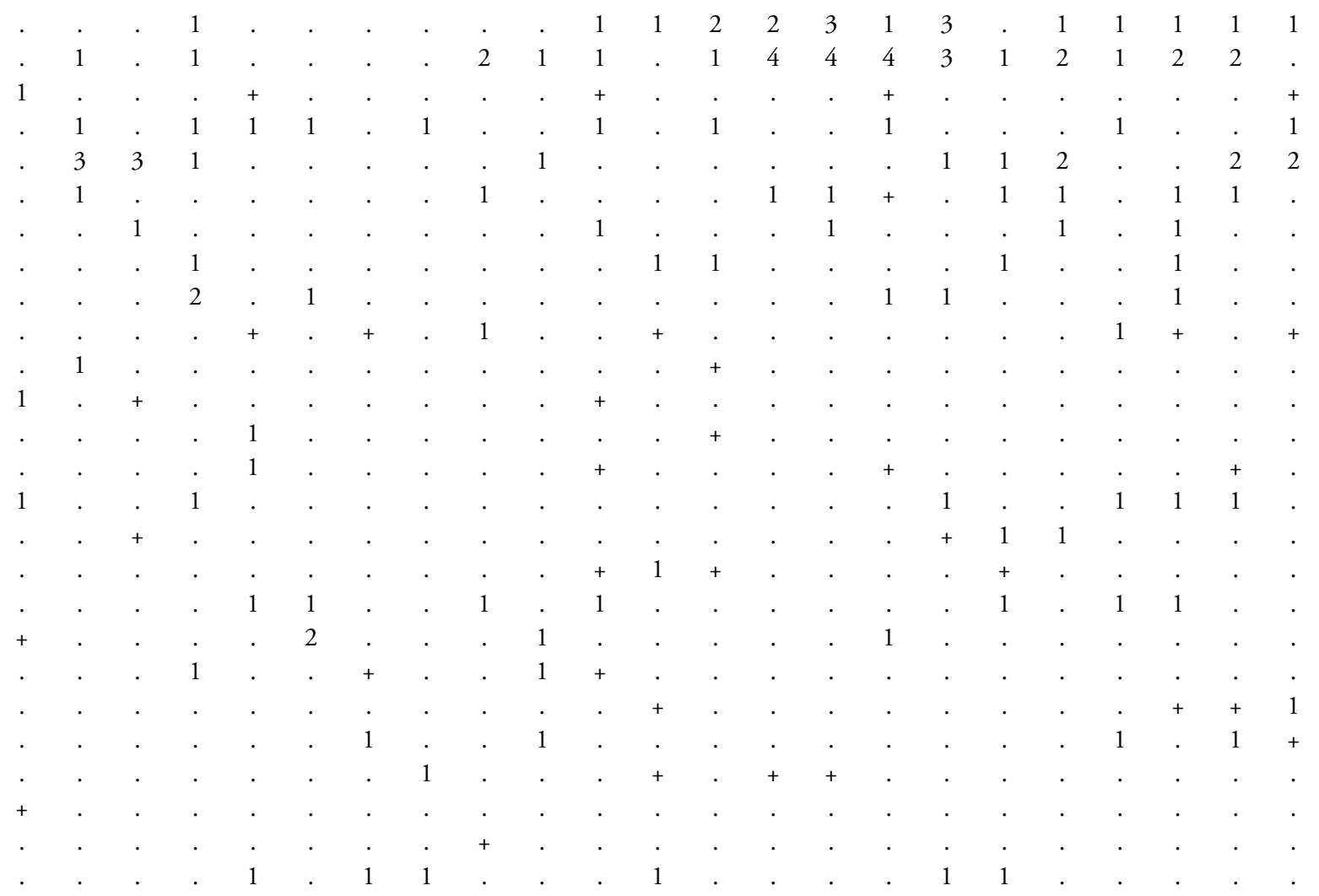




\begin{tabular}{lcccccccccccccccccc}
\hline Relevé № & 1 & 2 & 3 & 4 & 5 & 6 & 7 & 8 & 9 & 10 & 11 & 12 & 13 & 14 & 15 & 16 & 17 \\
Slope $\left({ }^{\circ}\right)$ & 7 & 3 & 1 & 5 & 7 & 7 & 3 & 2 & 5 & 2 & 7 & 7 & 3 & 3 & 10 & 15 & 3 \\
Aspect $\left({ }^{\circ}\right)$ & 50 & 270 & 10 & 320 & 320 & 40 & 30 & 270 & 340 & 0 & 10 & 345 & 345 & 360 & 320 & 300 & 0 \\
Cover $(\%)$ & 70 & 80 & 60 & 60 & 60 & 75 & 80 & 70 & 70 & 60 & 90 & 60 & 70 & 70 & 60 & 60 & 50 \\
\hline
\end{tabular}

Alyssum desertorum

Xeranthemum annum

Diagnostic species for the class Festuco-Brometea

Festuca valesiaca

Eryngium campestre

Stipa ucrainica

Euphorbia seguieriana

Koeleria cristata

Salvia nutans

Thymus $x$ dimorphus

Medicago falcata

Salvia nemorosa aggr.

Thalictrum minus

Galium ruthenicum

Ornithogalum kochii

Tragopogon major

Bromopsis riparia

Stachys recta

Alyssum hirsutum

Achillea setacea

Oxytropis pilosa

Potentilla obscura

Potentilla argentea

Asparagus verticillatus

Veronica triphyllos

Asperula cynanchica

Securigera varia

Phlomis pungens

Carduus uncinatus

Convolvulus lineatus

Falcaria vulgaris

Erysimum diffusum

Verbascum phoeniceum

Pleconax subconica

Botriochloa ischaemum

Linum austriacum

\section{Other species}

Elytrigia repens

Consolida paniculata

Centaurea diffusa

Dactylis glomerata

Tortula ruralis

Anthemis ruthenica

$$
\begin{aligned}
& \begin{array}{llllllllllllllllll}
1 & 1 & 3 & 2 & 3 & . & . & 1 & 3 & 2 & . & 1 & 1 & 4 & 1 & 1
\end{array} \\
& \begin{array}{lllllllllllllllll}
. & 1 & 1 & + & 1 & 1 & 1 & . & 1 & . & . & . & 1 & . & 1 & . & . \\
. & . & . & . & . & . & . & 2 & . & . & . & . & . & . & . & . & . \\
. & 1 & + & 1 & . & 1 & 1 & 1 & . & 1 & . & . & . & 1 & . & . & 1
\end{array} \\
& 2
\end{aligned}
$$

Species of low frequencies: Achillea millefolium (3:1), Adonis aestivalis (11:+), Aegilops triuncialis (15: 1; 16: 1), Agropyron cimmericum (14:+), A. desertorum (19: 1), Ajuga chia (26: +; 37: 1), A. orientalis (27: 1), Alcea rugosa (10: +; 27: +), Allium firmotunicatum (10: +), A. paczoskianum (14: +; 24: +; 38: +), A. rotundum (34: 1; 36: +), Alopecurus vaginatus (15: +; 17: 2), Alyssum tortuosum (17: 1), Amygdalus nana (38: 1), Anisantha tectorum (16: 1;39: 1), Anthemis cotula (31: +;32: +; 34: 1), A. tinctoria subsp. subtinctoria (7: 1), Artemisia lerchiana (16:2;17:1), A. marschalliana $(27: 1 ; 36: 1 ; 37: 1)$, A. santonicum $(12:+)$, A. taurica (11: 1;15:1;16:1), 


\begin{tabular}{cccccccccccccccccccccccc}
18 & 19 & 20 & 21 & 22 & 23 & 24 & 25 & 26 & 27 & 28 & 29 & 30 & 31 & 32 & 33 & 34 & 35 & 36 & 37 & 38 & 39 & 40 \\
3 & 7 & 2 & 3 & 7 & 10 & 7 & 3 & 7 & 5 & 7 & 10 & 5 & 20 & 15 & 25 & 15 & 20 & 5 & 3 & 7 & 5 & 2 \\
220 & 0 & 0 & 100 & 80 & 150 & 180 & 150 & 90 & 340 & 320 & 120 & 100 & 100 & 100 & 100 & 90 & 100 & 90 & 100 & 90 & 90 & 0 \\
50 & 70 & 60 & 80 & 85 & 55 & 70 & 85 & 75 & 60 & 70 & 70 & 80 & 85 & 85 & 85 & 75 & 75 & 90 & 75 & 70 & 60 & 70 \\
\hline
\end{tabular}

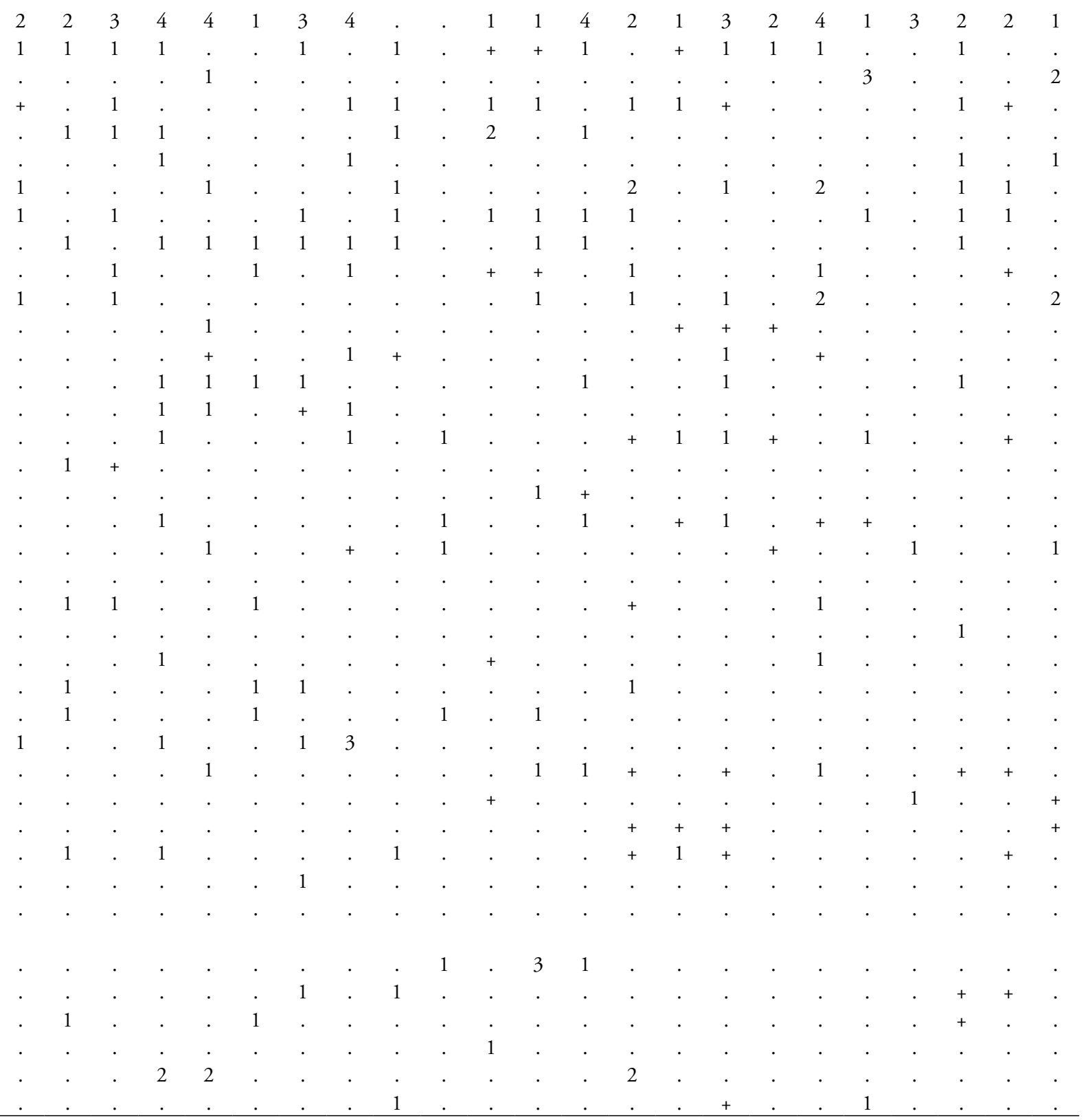


ucrainicum (33: 1), Cerinthe minor (28: +), Cladonia rangiformis (21: 1), C.sp. (14:+), Cleistogenes bulgarica (22: 1), C. squarrosa (39: 1), Convolvulus arvensis (25: +; 38: +), Crambe aspera (7: +), Crepis tectorum (8: +; 26: 1;33:+), Cruciata pedemontana (1: 1), Crupina vulgaris (4: +; 12:+), Cynanchum acutum (23: +), Cynodon dactylon (2: 1; 13: 1; 37: 2), Dianthus carbonatus (38: +), Dianthus pallidiflorus (23: 1; 24: +; 39:+), D. platyodon (37: 1; 39: +), Dichodon viscidum (22: 1; 33:+), Echium biebersteinii (10: +), E. vulgare (24: 1), Elytrigia elongata (6: 1; 12: 1), E. maeotica (39: 1), Eremogone rigida (22:1), Erodium cyconium (8: +), Erophila verna (27: 1), Erysimum repandum (10:+), Filago arvensis (26: +), Filipendula vulgaris (9: 1; 11:1), Gagea dubia (29: +), Galatella dracunculoides (5: 2; 31: 1), G. rossica (13: 1), Galium tenuissimum (9: +), G. volhynicum (22: +), Glycyrrhiza glabra (24: 1), Goniolimon rubellum (19: +), Gypsophila paniculata (16: +; 24: 1; 39: +), Herniaria besseri (26: 1; 34: 1; 37: 1; 38: 1), Hesperis tristis (2: +; 8: +), Hieracium sp. (17: +; 19: +; 20: +), H. umbellatum (13: +; 28: +; 34: +), H. virosum (34:+), Hypericum perforatum (2: +; 6: 1; 39: +), Inula aspera $(2:+; 5: 1 ; 31:+)$, I. germanica (6: 1), I. oculus-christi (20:+), Jurinea granitica (31: +), J. multiflora (36: +; 38: +), J. sordida (13: +), Koeleria glauca (39: +), Lactuca serriola (5: +; 26: +), Lamium amplexicaule (27: 1), Lathyrus tuberosus (1: +; 9: 1), Ligustrum vulgare (31: +), Limonium gmelinii (12: +), L. sareptanum (26: +; 29: +; 39: +), Linaria vulgaris (5: +), Marrubium praecox (28: +; 36: 1), Medicago minima (37: +), M. praecox (8: +; 18:+), Melandrium album (32: 1; 35:+), Melica transsilvanica (14: 1), Meniocus linifolius (21: +; 25: 1; 33:+), Milium vernale (9: +), Muscari neglectum (27:+), Myosotis micrantha $(25:+; 33:+; 35: 1)$, Nonea rossica (21: +), Onobrychis viciifolia $(7: 1 ; 9: 1 ; 11:+; 40:+)$, Onosma rigida $(3:+; 14:+)$, O. tinctoria $(7:+; 9:+)$, Ornithogalum flavescens $(7:+; 15:$ +), O. melancholicum (23: +), Pastinaca clausii (1: 1; 22: +), Phelipanche lanuginosa (27: 1), Phleum phleoides (39: 1), Phlomis hybrida $(22:+)$, Plantago lanceolata $(2:+)$, P. lanceolata subsp. lanuginosa $(7: 1 ; 25: 1)$, P. urvillei $(11: 1 ; 14:+; 27: 1)$, Polycnemum arvense (39: +), Polygala major (9: 1), Polygonum aviculare (38: +), Potentilla semilaciniosa (29: +), Prangos odontalgica (1: 1), Pterotheca sancta $(12:+)$, Ranunculus oxyspermus $(21: 1 ; 23: 1)$, Reseda lutea $(23:+; 33:+)$, Rosa adenodonta $(21:+), 32: 1)$, Syrenia montana (37: +), Taraxacum erythrospermum (27: 1), Teucrium chamaedrys (6: 1; 17: 1), T. krymense (3: 1; 10:1; 14: 1), Thymelaea passerina (22: +), Thymus calcareus (14: 1), T. marschallianus (27: 1; 29: 1; 37: 1), Trifolium arvense (37: 1), T. campestre (5: 1), Trinia hispida (4: +; 10: +; 20: +), Tulipa ophiophylla $(22:+; 32:+)$, T. gesneriana (3: +), Valeriana tuberosa $(22:+; 31:+)$, Valerianella carinata (15: +; 16: +), V. costata (22: 1), V. turgida (5: 1; 12: +; 14: +), Verbascum densiflorum (23: +; 24: 1; 38: +), Veronica peregrina (16: +), V. polita (15: 1), V. praecox (32: +), V. sp. (4: 1), V. spicata (29: 1), V. triloba (15:+), V. verna (8: +; 12: +; 18: +), Vicia angustifolia (1: 1), V. cracca (23: +), V. tetrasperma (5: 1), Viola kitaibeliana $(25: 1 ; 35:+)$.

\section{Localities:}

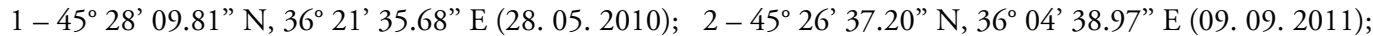

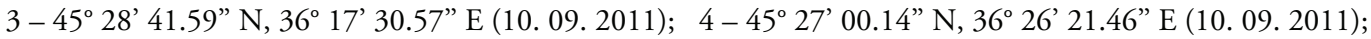

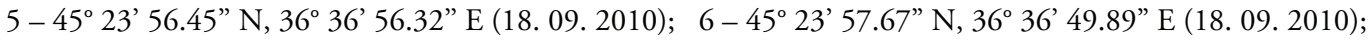
7 - $45^{\circ} 26^{\prime} 54.06^{\prime \prime} \mathrm{N}, 36^{\circ} 05^{\prime} 36.78^{\prime \prime} \mathrm{E}(07.06 .2009) ; 8-45^{\circ} 19^{\prime} 16.38^{\prime \prime} \mathrm{N}, 35^{\circ} 38^{\prime} 50.54^{\prime \prime} \mathrm{E}(08.06 .2009)$; $9-45^{\circ} 28^{\prime} 14.47^{\prime \prime} \mathrm{N}, 36^{\circ} 12^{\prime} 13.17^{\prime \prime} \mathrm{E}$ (08. 06. 2009); $10-45^{\circ} 17^{\prime} 40.71^{\prime \prime} \mathrm{N}, 35^{\circ} 33^{\prime} 23.31^{\prime \prime} \mathrm{E}$ (30. 06. 2011);

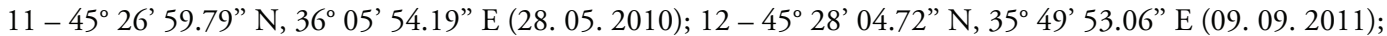
13 - $45^{\circ} 28^{\prime} 07.46^{\prime \prime} \mathrm{N}, 35^{\circ} 49^{\prime} 55.76^{\prime \prime} \mathrm{E}(09.09 .2011) ; 14-45^{\circ} 28^{\prime} 46.84^{\prime \prime} \mathrm{N}, 36^{\circ} 17^{\prime} 37.32^{\prime \prime} \mathrm{E}(10.09 .2011)$;

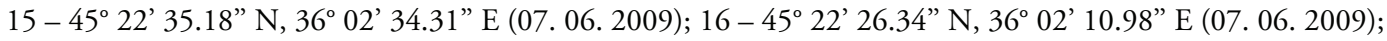
$17-45^{\circ} 26^{\prime} 50.03^{\prime \prime} \mathrm{N}, 36^{\circ} 05^{\prime} 18.17^{\prime \prime} \mathrm{E}(07.06 .2009) ; 18-45^{\circ} 19^{\prime} 16.91^{\prime \prime} \mathrm{N}, 35^{\circ} 38^{\prime} 48.55^{\prime \prime} \mathrm{E}(08.06 .2009)$; $19-45^{\circ} 19^{\prime} 52.46^{\prime \prime} \mathrm{N}, 35^{\circ} 41^{\prime} 41.83^{\prime \prime} \mathrm{E}(30.06 .2011) ; 20-45^{\circ} 17^{\prime} 45.34^{\prime \prime} \mathrm{N}, 35^{\circ} 33^{\prime} 33.31^{\prime \prime} \mathrm{E}(30.06 .2011)$;

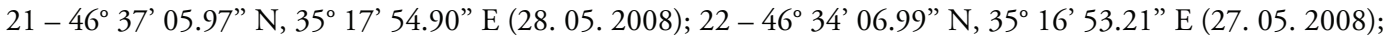
23 - 46 46'32.99” N, 36 50' 54.38” E (05. 05. 2002); $24-47^{\circ} 05^{\prime} 37.49^{\prime \prime} \mathrm{N}, 37^{\circ} 42^{\prime} 56.80^{\prime \prime}$ E (29. 07. 2010); $25-46^{\circ} 56^{\prime} 17.96^{\prime \prime} \mathrm{N}, 37^{\circ} 10^{\prime} 35.65^{\prime \prime} \mathrm{E}(05.06 .2010) ; 26-46^{\circ} 32^{\prime} 29.85^{\prime \prime} \mathrm{N}, 35^{\circ} 17^{\prime} 40.86^{\prime \prime} \mathrm{E}(26.07 .2011)$; $27-45^{\circ} 16^{\prime} 29.47^{\prime \prime} \mathrm{N}, 36^{\circ} 57^{\prime} 16.26^{\prime \prime} \mathrm{E}(15.04 .2011) ; 28-45^{\circ} 25^{\prime} 56.81^{\prime \prime} \mathrm{N}, 36^{\circ} 34^{\prime} 21.10^{\prime \prime} \mathrm{E}(10.09 .2011)$; $29-46^{\circ} 06^{\prime} 24.87^{\prime \prime} \mathrm{N}, 38^{\circ} 01^{\prime} 55.37^{\prime \prime}$ E (19. 04. 2012); $30-46^{\circ} 38^{\prime} 07.57^{\prime \prime} \mathrm{N}, 35^{\circ} 50^{\prime} 48.16^{\prime \prime} \mathrm{E}(20.05 .2012)$; $31-46^{\circ} 34^{\prime} 02.76^{\prime \prime} \mathrm{N}, 35^{\circ} 17^{\prime} 01.05^{\prime \prime} \mathrm{E}$ (27. 05. 2008); $32-46^{\circ} 37^{\prime} 05.10^{\prime \prime} \mathrm{N}, 35^{\circ} 17^{\prime} 54.68^{\prime \prime} \mathrm{E}$ (27. 05. 2008); $33-46^{\circ} 37^{\prime} 07.02^{\prime \prime} \mathrm{N}, 35^{\circ} 17^{\prime} 54.58^{\prime \prime}$ E (27. 05. 2008); $34-46^{\circ} 37^{\prime} 09.27^{\prime \prime} \mathrm{N}, 35^{\circ} 17^{\prime} 54.48^{\prime \prime} \mathrm{E}$ (15. 06. 2008);

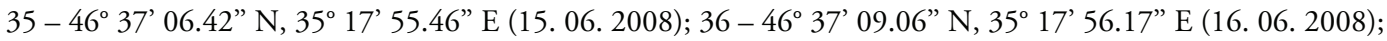
$37-46^{\circ} 33^{\prime} 03.85^{\prime \prime} \mathrm{N}, 35^{\circ} 17^{\prime} 41.20^{\prime \prime} \mathrm{E}(02.07 .2004) ; 38-46^{\circ} 41^{\prime} 42.07^{\prime \prime} \mathrm{N}, 35^{\circ} 16^{\prime} 58.24$ ” E (15. 08. 2010); $39-46^{\circ} 37^{\prime} 33.24^{\prime \prime} \mathrm{N}, 35^{\circ} 17^{\prime} 00.10^{\prime \prime} \mathrm{E}(15.08 .2010)$; $40-46^{\circ} 42^{\prime} 02.42^{\prime \prime} \mathrm{N}, 35^{\circ} 17^{\prime} 08.63^{\prime \prime} \mathrm{E}(21.05 .2010)$ : 